\title{
ARTICLE
}

\section{Unpacking the Rise of Benefit Corporations: A Transatlantic Comparative Case Study}

\author{
SCOTTT J. SHACKELFORD JD, JANINE HILLER, \& XiAO MA*
}

The increasing interest in social entrepreneurship has brought with it the beginnings of a legal revolution in the way that firms are incorporated and managed. Thirty-four states have enacted statutes permitting the formation of special corporate entities known as benefit corporations. These businesses are required to pursue a public benefit or community purpose while still earning a profit for their shareholders. Yet not all benefit corporation statutes are created equal. V arying top-down and bottom-up approaches were taken to enact these laws, which may contribute to different success rates in terms of the number of benefit corporations created in the preceding years. In order to identify governance best practices that could inform other states and nations debating similar legislation, this Article analyzes the different ways that benefit corporation statutes are created in Virginia, Connecticut, and Delaware. This process of adoption and resulting incorporation of entities is then compared to the European Union's efforts at regulating social entrepreneurship, with a particular focus on the United Kingdom's Community Interest Company Approach. Through this lens, the Article investigates the processes and supporters of benefit corporation statutes, and compares theses with EU efforts to support social enterprises, in order to better understand how experimentation with legally unique forms of business contribute to current efforts to modify the relationship between business and society.

* Chair, Indiana University-Bloomington Cybersecurity Program; Associate Professor of Business Law and Ethics, Indiana University Kelley School of Business; Executive Director, Ostrom Workshop; Professor of Business Law, Richard Sorensen Professor in Finance, Pamplin College of Business, Virginia Tech; JD, Maurer School of Law; Associate at King \& Wood Mallesons. 
I. INTRODUCTION.

II. A BRIEF HISTORY OF BENEFIT CORPORATIONS: RATIONALE AND

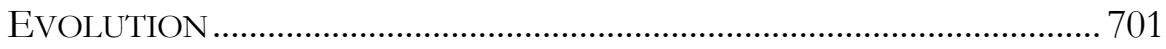

III. U.S. CASE STUDIES IN BENEFIT CORPORATION FORMATION ...... 702

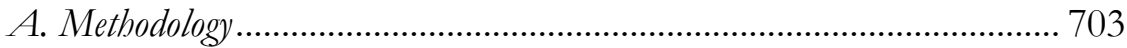

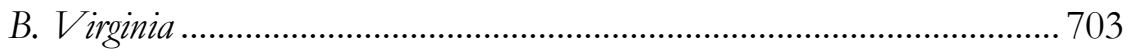

1. The History of Benefit Corporation Legislation Campaign in Virginia

2. Stakeholder Advocacy for the Virginia Benefit Corporation Legislation

705

3. Local Impact of Benefit Corporation Legislation .................................. 707

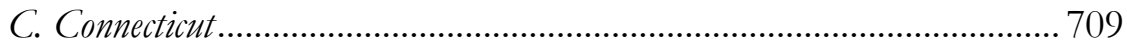

1. The History of the Benefit Corporation Legislation Campaign in

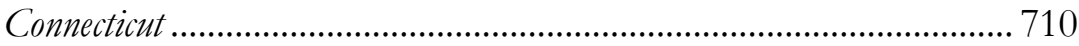

2. Stakeholder Advocacy for the Connecticut Benefit Corporation Legislation 713

3. Local Impact of Benefit Corporation Legislation .................................. 715

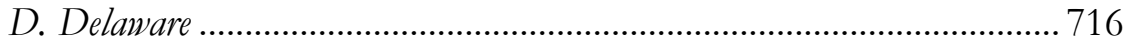

1. The History of the Benefit Corporation Legislation Campaign in Delaware 717

2. Stakeholder Advocacy for Delaware Benefit Corporation Legislation... 720

3. Local Impact of Benefit Corporation Legislation ................................... 722

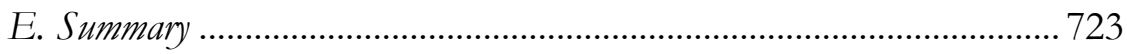

IV. TRANSATLANTIC APPROACHES TO DEFINING "SOCIAL

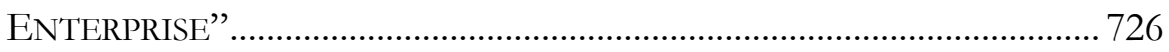

A. Unpacking European Socially Responsible Corporate Law ..................... 727

B. Case Study: The United Kingdom's Community Interest Company Approach

C. Looking Ahead and Applying Lessons Learned ..................................... 733

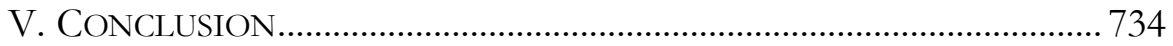




\section{INTRODUCTION}

From outdoor-gear-for-good companies to craft firms like Etsy to the crowd-funding site Kickstarter, more than 2,000 businesses have incorporated as either benefit corporations or have voluntarily certified as "BCorps" as of January 2019.1 Entrepreneurs are becoming increasingly bold in choosing this corporate form. Series entrepreneur Davis Smith, for example, explained: "If there's an investor that won't invest in me because I founded a benefit corporation, that's not the right investor for us." 2 This trend has mirrored a growing number of U.S. states that passed-or are in the process of enacting-benefit corporation statutes that can potentially impact everything from business ethics training to Board decision-making, with wide-ranging implications for the economy, environment, and civil society. ${ }^{3}$

Mission-led business, social entrepreneurship, social enterprise, and other terms are all used to describe the movement toward a kind of business that lies somewhere between completely profit-driven enterprises and nonprofit organizations. The varying, yet internationally recognized, dichotomy between capitalism and community, self-interest and society, profit and purpose, is diminished by new forms of legal business entities and the individual social entrepreneurs who embrace them. One of the most intriguing new forms of business that envisions a new place for business in society is the benefit corporation, a legal designation adopted by thirty-four U.S. states and now at least one other country, Italy. ${ }^{4}$ Likewise, the United Kingdom's Community Interest Company (CIC) and the recently proposed modifications to the U.K. Corporate Governance Code (CGC) reflect potential paradigm shifts. ${ }^{5}$

1. See Eillie Anzilotti, This Outdoor-Gear-for-Good Company Proves You Can Be a Benefit Corporation from Day One, FAST COMPANY (June 22, 2017), https://www.fastcompany.com/40433532/this-outdoorgear-for-good-company-proved-you-can-be-a-benefit-corporation-from-day-one; B Corp Directory, BCORPORATION.NET, https:/ / bcorporation.net/directory (last visited May 29, 2020).

2. Anzilotti, supra note 1.

3. See Jamie Raskin, The Rise of Benefit Corporations, NATION (June 8, 2011), http://tiny url.com/zp $75 \mathrm{ch} 7$. It is worth noting though that, before benefit corporation statutes were passed by state legislatures, companies like Kickstarter could nonetheless choose to join a voluntary certification known as a "BCorp," which is a choice that many firms such as Ben \& Jerry's, Patagonia, and Seventh Generation have made. B Corp Directory, supra note 1. The voluntary certification is replaced by a new legal form of business, the benefit corporation, when state statutory options are made available, as in the thirty-three states that have benefit corporation statutes as of September 2017. See State by State Status of Legislation, BENEFIT CORP., http://benefitcorp.net/policymakers/state-by-state-status (last visited Jan. 30, 2019).

4. See id.

5. See UK Corporate Governance Code, FIN. REPORTING COUNCIL, https://www.frc.org.uk/ directors/corporate-governance-and-stewardship/uk-corporate-governance-code (last visited Jan. 30, 2019). 
This Article analyzes the new legal form for socially responsible and mission-led businesses reflected in benefit corporations in the United States, and the CIC and draft CGC in the United Kingdom. Legal institutions play an important role in the social enterprise evolution, yet the impact of legal forms of business have received less attention in the literature to date. ${ }^{6}$ This Article provides evidence of the comparative, dynamic nature of issue and stakeholder engagement in adopting new forms of socially focused business entities law, and the process's potential for success.

Socially responsible business entrepreneurship has brought with it the beginnings of a legal revolution, but these changes were not uniform. In the United States, varying state-level corporate law makes it possible to study differing processes that led to Benefit Corporation adoption, the unique actors/stakeholders involved, varying economic conditions, and the goals of the legislation. This Article analyzes the differences among Virginia, Connecticut, and Delaware in enacting benefit corporation laws, and investigates early successes and challenges post-enactment, in an effort to identify governance best practices that could inform other states and nations debating similar legislation. These states utilized various top-down and bottom-up approaches in enactment, which we argue contributed to different success rates in the number of benefit corporations created. We then compare this process to the European Union's efforts to regulate social entrepreneurship, with a particular focus on the United Kingdom's Community Interest Company Approach. Through this lens, the Article investigates the processes and purposes of benefit corporation statutes in order to better understand current efforts to modify the nature of the relationship between business and society.

The Article is structured as follows. Part II briefly discusses the rise and evolution of benefit corporations, primarily in the U.S. context where they began. This discussion sets the stage for Part III in which the three state case studies are analyzed. Part IV then globalizes the discussion by comparing and contrasting the U.S. experience in enacting benefit corporation laws with the EU experience in social entrepreneurship. The Article concludes with a summary of governance best practices and practical ideas for a research agenda moving forward.

6. See Blanche Segrestin \& Armand Hatchuel, The Shortcomings of the Corporate Standard: Towards New Enterprise Frameworks?, 22 INT’L REV. APPLIED ECON. 429, 429 (2008). 


\section{A BRIEF History OF BENEFIT CORPORATIONS: RATIONALE AND EVOLUTION}

Although opinions diverge, some scholars contend that there have been four primary transformations in the history of corporate law since Roman times. ${ }^{7}$ Under this view, the first vision of corporate governance was of the firm as a legal, non-profit organization centered on promoting the public good. 8 Then from the mid-fourteenth to the nineteenth centuries, corporations gradually became for-profit entities. ${ }^{9}$ The third stage involved corporations moving from closely-held to widely-held management structures ${ }^{10}$ that eschewed localized self-governance. The fourth and final innovation was the expansion of corporations from national to truly multinational enterprises. ${ }^{11}$

The "new" corporate law, manifested primarily by the rise of benefit corporations, resulted from the wave of social entrepreneurship beginning in the athletic shoe industry. ${ }^{12}$ The former owners of AND1 worked with attorney William Clark to develop the first Model Benefit Corporation Act, which has since been propounded to state legislatures across the nation. ${ }^{13}$ To aid in this effort, the group also created the non-profit B Lab, whose purposes are to: (1) promote benefit corporation legislation and the fundamental shift in corporate perspective it codified, (2) provide a vehicle for companies to become certified as BCorps in order to "meet the highest standards of verified, overall social and environmental performance, public transparency, and legal accountability," (3) provide an assessment and analytical metrics to "Measure What Matters," and (4) create a narrative to "inspire[e] millions to join the movement." 14 Specifically, B Lab has provided expert testimony, drafting comments, ${ }^{15}$ and pro bono legal

7. See Timothy L. Fort, Business, Integrity, And Peace: Beyond Geopolitical and DISCIPLINARY BOUNDARIES 86 (2011)

8. Id.

9. Id. at $86-87$.

10. Id. at 87 .

11. Id.

12. Stephen M. Bainbridge, Director Primacy: The Means and Ends of Corporate Governance, 97 NW. U. L. REV. 547, 549 (2003).

13. See Janine S. Hiller, The Benefit Corporation and Corporate Social Responsibility, 118 J. Bus. ETHICS 287 (2013); Susan Adams, Capitalist Monkey Wrench, FORBES (Mar. 25, 2010), https://tinyurl.com/ y9gfzg4z; Maryland First State in Union to Pass Benefit Corporation Legislation, CSRWIRE (Apr. 14, 2010, 10:57 AM), http://tinyurl.com/ztmd2sb.

14. William H. Clark, JR. \& LaRry VRanka, Benefit Corp., The NeEd and Rationale FOR THE BENEFIT CORPORATION: Why IT IS THE LEGAL FORM THAT BEST ADDRESSES THE NeEds of Social Entrepreneurs, Investors, And, Ultimately, the Public (2013), http://benefitcorp.net/sites/default/files/Benefit_Corporation_White_Paper.pdf.

15. See Model Benefit Corporation Legislation with Explanatory Comments, BENEFIT CORP. (June 24, 2014), http:// tinyurl.com/hpd5a3z. 
services for drafting legislation. ${ }^{16}$ These efforts have paid off. B Lab's success in its lobbying efforts is shown by the growth of benefit corporation laws in U.S. states; Maryland was the first state to sign its benefit corporation legislation into law in April 2010, and as of September 2017, thirty-four states have laws on the books, with another six considering adoption. ${ }^{17}$

Scholars have previously analyzed benefit legislation in some detail. ${ }^{18}$ For the present purposes, the primary attributes of a benefit corporation (unlike BCorps) are that: (1) its purpose must include either a general or specific public benefit; (2) as part of their fiduciary duties, directors must consider broader stakeholder interests as well as profit; and (3) the entity must assess its performance annually, reporting about the benefits delivered, by using a third-party assessment. ${ }^{19}$ However, despite their success, not all benefit corporation statutes are created equal. Indeed, the process used to enact these laws, we argue, may well have had an impact on the popularity of this new corporate form in various states. To test this theory, Part III does a deep dive into the experiences of three states-Virginia, Connecticut, and Delaware-in an effort to ascertain governance best practices for other jurisdictions, both in the United States and abroad, that are considering similar measures.

\section{U.S. CASE STUDIES IN BENEFIT CORPORATION FORMATION}

Building from the groundwork laid in Part II, this Part investigates the experiences of three states-Virginia, Connecticut, and Delaware-in passing benefit corporation statutes. In so doing, this Part aims to offer what some scholars, including Professor William Boyd, have called for in another context, namely a "more thick description[ of how these forms of governance are taking shape," and to pay more "attention to the connective tissues that bind and hold these forms together." 20

16. See id.

17. See State by State Status of Legislation, supra note 3.

18. See generally Annie Collart, Benefit Corporations: A Corporate Structure to Align Corporate Personhood with Societal Responsibility, 44 SETON HALl L. REV. 1160, 1176-81 (2014); Joseph Karl Grant, When Making Money and Making a Sustainable and Societal Difference Collide: Will Benefit Corporations Succeed or Fail?, 46 IND. L. REv. 581, 582-88 (2013); J. Haskell Murray, Choose Your Own Master: Social Enterprise, Certifications, and Benefit Corporation Statutes, 2 AM. U. BUS. L. REV. 1, 1 (2012); Thomas J. White III, Benefit Corporations: Increased Oversight Through Creation of the Benefit Corporation Commission, 41 J. LEGIS. 329, 339-46 (2015).

19. See William H. Clark, Jr. \& Elizabeth K. Babson, How Benefit Corporations Are Redefining the Purpose of Business Corporations, 38 WM. MiTCHELL L. REV. 817, 838-39 (2012).

20. William Boyd, Climate Change, Fragmentation, and the Challenges of Global Environmental Law: Elements of a Post-Copenhagen Assemblage, 32 U. PA. J. INT'L L. 457, 516 (2010). 


\section{A. Methodology}

A qualitative, comparative case study approach was used to study the enactment of the three benefit corporation laws in these states. ${ }^{21}$ The three case studies were created by first reviewing publicly available documents from each state's legislative databases. ${ }^{22}$ These findings were supplemented through the Westlaw state news database, each state's corporation registration database, ${ }^{23}$ and communication between policymakers. ${ }^{24}$ These data were then used to analyze: (1) the economic performance of each state including the fastest-growing sectors as context to help discern the state's legislative intent, (2) legislative history as a proxy for studying lobbying efforts, (3) stakeholder advocacy with regards to the level of institutional involvement and professional leadership in advocating for benefit corporations, (4) the number of benefit corporations that were incorporated after the passage of the relevant statute, and (5) local media coverage as a proxy for how, generally, engaged civil society was with the passage of each statute.

\section{B. Virginia}

According to data released by the Bureau of Economic Analysis, ${ }^{25}$ Virginia's gross domestic product (GDP) growth rate was 0.6 percent during

21. See Gary King, Robert O. KeOHAne \& Sidney Verba, Designing Social Inquiry: SCIENTIFIC INFERENCE IN QUALiTATIVE RESEARCH 1-10 (1994); Bruce Bueno de Mesquita, The Benefits of a Social-Scientific Approach to Studying International Affairs, in EXPLAINING INTERNATIONAL RELATIONS SINCE 1945, at 49 (Ngaire Woods ed., 1996). These states were chosen given Delaware's central importance in corporate law, Connecticut's growing corporate management sector coupled with the relatively more difficult path in passing its benefit corporation statute, and Virginia's nearly frictionfree approval process.

22. See Bill Information Search, CONN. GEN. ASSEMBLY, https://www.cga.ct.gov/ asp/CGABillInfo/CGABillInfoRequest.asp (last visited Oct. 29, 2017); Bill Search, DEL. GEN. ASSEMBLY, http://legis.delaware.gov/ (last visited Oct. 29, 2017); VA.'S LEGIS. INFO. SYS., http://lis.virginia.gov/ (last visited Oct. 29, 2017).

23. See Business Entity Search, VA. ST. CORP. COMmISSION, https://sccefile.scc.virginia.gov/ Find/Business (last visited Oct. 29, 2017); Connecticut Business Registry Search, CONN. SECRETARY ST., http://www.concord-sots.ct.gov/CONCORD/online?sn=PublicInquiry\&eid=9740 (last visited Oct. 29, 2017); Division of Corporations, ST. DEL.: DEP'T ST., https://icis.corp.delaware.gov/Ecorp/Entity Search/NameSearch.aspx (last visited Oct. 29, 2017).

24. See also E-mail from Richard J. Geisenberger, Chief Deputy Secretary of State, Delaware Department of State, to Tanner Wm. Polce, Legislative Aide of Delaware State Senate (Feb. 1, 2016) (on file with author).

25. Gross Domestic Product by State: 1st Quarter 2017, BuREAU ECON. ANALYSIS (July 26, 2017), https://www.bea.gov/news/2017/gross-domestic-product-state-1st-quarter-2017. 
2015-2016, ${ }^{26}$ but increased to 4.2 percent by $2018 .{ }^{27}$ The Commonwealth was responsible for more than $\$ 494$ billion towards the U.S. GDP in 2016,28 representing 2.7 percent of the total. ${ }^{29}$ Only fifteen states consistently contributed over two percent of U.S. GDP in the past four years, ${ }^{30}$ and Virginia was a member of this leading group. ${ }^{31}$

Information Technology (IT) contributed the most to Virginia's GDP growth from 2013 to 2014,32 while health care and social assistance was the second fastest-growing sector. 33 The two most recessive sectors were Construction and Nondurable goods; these sectors' negative contributions to Virginia's GDP's percent change in 2013 were nineteen percent and fifteen percent, respectively. ${ }^{34}$ Due to the growth in IT during this time, one could imply generally that Virginia was a state embracing innovation, investment, job creation in this higher-tech environment.

\section{The History of Benefit Corporation Legislation Campaign in Virginia}

In 2011, Virginia became the fourth state to pass benefit corporation legislation by enacting the Virginia Benefit Corporation Bill, ${ }^{35}$ authored and sponsored by Delegate Jennifer McClellan. ${ }^{36}$ The bill was co-sponsored by

26. Table 1, Percent Change in Real Gross Domestic Product (GDP) by State, 2016:Q1-2017:Q1, BUREAU ECON. ANALYSIS (July 26, 2017), https://www.bea.gov/news/2017/gross-domestic-product-state1st-quarter-2017 (select tab "Related Materials," then select "Release Tables Only" to open Excel document).

27. Gross Domestic Product by State, 2nd quarter 2018, BUREAU ECON. ANALYSIS (Nov. 14, 2018), https://www.bea.gov/news/2018/gross-domestic-product-state-2nd-quarter-2018.

28. Table 3, Current-Dollar Gross Domestic Product (GDP) by State, 2016:Q1-2017:Q1, BUREAU ECON. ANALYSIS (July 26, 2017), https://www.bea.gov/news/2017/gross-domestic-product-state-1stquarter-2017 (select tab "Related Materials," then select "Release Tables Only" to open Excel document).

29. See id.

30. The fifteen states include California (14.2\%), Texas (8.6\%), New York (8.1\%), Florida (5.0\%), Illinois (4.3\%), Pennsylvania (3.9\%), Ohio (3.4\%), New Jersey (3.1\%), North Carolina (2.8\%), Georgia $(2.9 \%)$, Virginia (2.7\%), Massachusetts (2.7\%), Michigan (2.6\%), Washington (2.6\%) and Maryland $(2.1 \%)$. See Regional Data: GDP and Personal Income, BUREAU ECON. ANALYSIS, https://tinyurl.com/y84jpa8t (last visited May 29, 2020).

31. From 2013-2016, the percentage of overall U.S. GDP that Virginia contributed every year was $2.7 \% .2 .7 \%, 2.7 \%$ and $2.7 \%$, respectively. See $i d$.

32. Table 2, Contribution to Percent Change in Real GDP by State, 2013-2014, BUREAU ECON. ANALYSIS (June 10, 2015), https://www.bea.gov/news/2015/gross-domestic-product-state-advance2014-and-revised-1997-2013 (select tab "Related Materials," then select "Tables Only" to open Excel document) (specifying twenty-one sectors from Agriculture to Government with the information sector contributing 15\% to Virginia GDP's percent change from 2013-2014).

33. Health care and social assistance contributed $12 \%$ to Virginia GDP's percent change from 2013-2014. Id.

34. Id.

35. H.B. 2358, Gen. Assemb., 2011 Sess. (Va. 2011).

36. HB 2358 Benefit corporations; definition, requirements, VA.'S LEGIS. INFO. SYS., http:/ lis.virginia. gov/cgi-bin/legp604.exe?111+sum+HB2358 (last visited Oct. 29, 2017) [hereinafter HB 2358 information]. 
six House members. ${ }^{37}$ Importantly, the Business Law Section of the Virginia Bar Association supported the bill and "worked with Del. Jennifer McClellan in securing passage." 38

The bill passed quickly and encountered almost no opposition. It was referred to the Committee on Commerce and Labor on January 12, 2011 and received twenty positive out of twenty-two votes on January $27.39 \mathrm{On}$ February 2, 2011, the Virginia House of Delegates passed the benefit corporation legislation without any negative votes. ${ }^{40}$ Virginia's Senate unanimously passed the legislation on February 23, 2011, and it was signed into law by Governor Bob McDonnell on March 26, 2011, with an effective date of July 1, 2011.41

\section{Stakeholder Advocacy for the Virginia Benefit Corporation Legislation}

The story of Virginia's adoption of the benefit corporation began with one individual, Michael Pirron, who read about Maryland's law and forwarded a copy to his legislative representative, Delegate Jennifer McClellan. ${ }^{42}$ Pirron's company, Impact Makers, was "a Richmond-based technology consulting firm that want[ed] to become a model in Virginia for the small but growing 'social enterprise' movement." 43 Impact Makers was a purely for-profit business that wanted to nevertheless devote its profits to social benefit uses. Its founder described the benefit corporation form as "a great model," because "it leverages all the power of capitalism-the value proposition to clients and the job creation, and it also has a community impact." 44

Delegate McClellan confirmed the bottom-up nature of the movement and the potential for growth, stating: "I do know there are already about 15 companies in Virginia who have expressed an interest in becoming benefit corporations ... I think it is an idea that will catch on." 45 She also pointed out that, "there are no tax breaks, credits or other financial incentives to go along with the benefit corporation category," 46 those interested in creating a legal benefit corporation do so primarily to align business purposes with

37. Id. (Robert Brink, Benjamin Cline, Rosalyn Dance, Charniele Herring, Kaye Kory and Scott Lingamfelter).

38. VA. BAr Ass'N, 2011 General Assembly Session: VBA Legislative Highlights (2011), https://tinyurl.com/yd7mkgg2 (last visited Jul. 11, 2020).

39. HB 2358 information, supra note 36.

40. Id.

41. Id.

42. John Reid Blackwell, Growing Number of Companies Have a Different Profit Motive, RICHMOND TIMES-DisPATCH, Mar. 13, 2011, 2011 WLNR 4961284.

43. $I$.

44. Id.

45. Id.

46. Chelyen Davis, Making Money, Doing Good, FreE LANCE-STAR (Fredericksburg, Va.), Feb. 26, 2011, 2011 WLNR 3789737. 
socially responsible practices, not for any direct monetary incentive. Delegate McClellan concluded that benefit corporation legislation would be attractive to both existing and new businesses in Virginia despite the lack of financial incentives. ${ }^{47}$ According to B Lab, benefit corporations can thrive due to "a pent-up consumer demand for these types of businesses," 48 because consumers want to support businesses with a social conscience. ${ }^{49}$ In addition, legislation authorizing benefit corporations could "reasonably be expected to" create jobs by attracting similar entities to the state. ${ }^{50}$

Institutionally, in addition to the support of the Virginia Bar Association, B Lab also played a significant role in Virginia benefit corporation advocacy. ${ }^{51} \mathrm{~B}$ Lab stated in its written testimony that, "there were more than 50,000 businesses in the U.S., they strive to create great jobs and local living communities. But they struggle with a capital market and corporate structures build [sic] for an old way of doing business." 52 B Lab argued that without benefit corporation law, businesses had only had two options: to make business decisions restricted by maximizing returns for shareholders and investors, or to opt for the non-profit form, with its own limitations. ${ }^{53}$ The benefit corporation structure would grant the business community the freedom to operate for profit with "a greater goal," 54 such as improving the local community and environment.

After the passage of the Benefit Corporation Bill, however, and notwithstanding the nearly unanimous support of the legislature, several law professors and lawyers voiced some hesitation. For instance, Daniel S. Kleinberger of the William Mitchell College of Law, pointed out that the benefit corporate law was not necessary because companies could label their social and environmental consciousness through private certifications, such as B Corp designations offered by B Lab. ${ }^{55}$ From his perspective, the new legal designation could make it easier for directors or officers to blame companies' losses caused by their incompetency on social goods. ${ }^{56}$ Similarly, Victoria Bjorklund, a retired partner at Simpson Thacher \& Bartlett LLP, who represented nonprofits for over thirty years, stated that this corporate structure would be dangerous for consumers who could not tell the

47. Id.

48. Blackwell, supra note 42.

49. Id. (quoting Erik Trojian, director of policy for B Lab) ("When consumers know they are out there, they tend to purchase from them.").

50. Davis, supra note 46.

51. Id.

52. Id.

53. Id.

54. Id.

55. Erin Chan Ding, CERTIFIED TO DO GOOD: B Corporations Go Beyond Profit, but Should Government Become Involved?, DAILY PRESS (Newport News, Va.), Aug. 9, 2012, at A10, 2012 WLNR 16895085.

56. Id. 
differences between non-profit and benefit corporations. ${ }^{57}$ She claimed this new corporate structure is "ripe for abuse." 58

\section{Local Impact of Benefit Corporation Legislation}

Despite the criticisms, though, a number of firms did take advantage of this new corporate form once it became available. According to the Virginia State Corporation Commission database, the number of benefit corporations rose from thirty-three in April 2015, to forty-six by March 2016.59 There were also twenty-two new benefit corporations that were converted or incorporated in Virginia between April 16, 2015 and March 17, 2016, and nine benefit corporations were either dissolved or stopped incorporating as a benefit corporation during the same period of time. ${ }^{60}$

The growing number of benefit corporations arguably helped to spur Virginia's economic growth and added to the wellbeing of the community. For example, Impact Makers, Inc.-aforementioned as a proponent of the legislation and one of Virginia's first B Lab certified benefit corporationsconverted to a benefit corporation in 2015. ${ }^{61}$ Since the company certified as a BCorp before the legal form became available in Virginia, the CEO of Impact Makers predicted that the benefit corporation form would help attract talent to the company because "[o]ur innovative and interesting business model really appeals to a lot of people." ${ }^{2}$ The evidence supports his expectation. Impact Makers was ranked among the nation's 500 fastest growing firms, ${ }^{63}$ with three-year revenue growth of 1,030 percent in $2012 .{ }^{64}$ The company donated $\$ 100,000$ to nonprofits in 2011,65 and contributed

57. Sarah Kleiner, Profit.. With Another Purpose, Virginian-PILOT (Sept. 9, 2013), https://www. pilotonline.com/business/article_7ea35c2d-8556-5ced-b306-e4e44b837bae.html.

58. Id.

59. See Mail from Janine S. Hiller, Professor of Business Law, Virginia Tech University, to Xiao Ma, JD Candidate of Indiana University Maurer School of Law (Apr. 19, 2016) (on file with author) [hereinafter Hiller Mail]. A list of all benefit corporations registered with Virginia State Corporation Commission at March 17, 2016 was pulled out from the state's database and was included in the mail (on file with author); see also E-mail from Janine S. Hiller, Professor of Business Law, Virginia Tech University, to Xiao Ma, JD Candidate of Indiana University Maurer School of Law (Mar. 15, 2016, 13:51 EST) (on file with author) [hereinafter Hiller E-mail]. A list of all benefit corporations registered with Virginia State Corporation Commission at April 16, 2015 was pulled out from the state's database and was attached to this E-mail (on file with author).

60. Hiller E-mail, supra note 59.

61. John Reid Blackwell, Impact Makers Gives Ownership of Firm to 2 Philanthropic Groups, RICHMOND Times-DisPaTCH, Apr. 29, 2015, at 1D, 2015 WLNR 12479252.

62. John Reid Blackwell, 4 Local Firms on List of 500 Fastest Growing, RiCHMOND TimES-DiSPATCH Aug. 22, 2012, 2012 WLNR 17745366.

63. Id.

64. Impact Makers, INC.COM, http://www.inc.com/profile/impact-makers (last visited Mar. 22, 2016); Inc. 5000 2012: The Full List, INC.COM, http://www.inc.com/inc5000/list/2012/ (last visited Mar. 22, 2018) (stating that revenues increased from $\$ 3.2$ million in 2012 to $\$ 11.6$ million in 2014).

65. Blackwell, supra note 62. 
approximately $\$ 300,000$ of financial and pro bono work in 2014.66 Since its creation, Impact Makers has given an estimated $\$ 1$ million in financial and pro bono work to the community. Norfolk Fair Trade Co. also exemplifies how the benefit corporation legislation helped attract investors and talent to the Commonwealth. 67 One backer invested her money in benefit corporations located in Richmond rather than Wall Street, because she was looking for an opportunity that had both social impact as well as financial interest. ${ }^{68}$

It does not seem that there was broader civil society engagement with the debate, as Virginia media's interest in following these developments was relatively stable from 2012 to 2015, except for a surge in 2014. According to the Westlaw "Virginia News" database, there were a total of twenty news reports regarding Virginia benefit corporation legislation from 2012 to 2015: four reports in 2012, three articles in 2013, seven in 2014, and four in 2015. In 2014, the majority of attention was given to one report that six hundred new jobs were coming to Fort Monroe, Virginia. ${ }^{69}$ Ironically, the six hundred jobs were promised by Liberty Source PBC, a Delaware public benefit corporation, ${ }^{70}$ as shown in Figure 1. Moreover, in 2016, the Virginia Community Capital (VCC) bank, a for-profit FDIC-insured banking entity, became a Virginia benefit corporation. ${ }^{71}$ VCC touted that it was "the first regulated bank in the United States of America to become a Benefit Corporation," and that " $[\mathrm{t}]$ he conversion will attract new investors to help communities and people all across the Commonwealth of Virginia prosper." 72

66. Blackwell, supra note 61.

67. This Virginia benefit corporation helps young entrepreneurs start their business and sell fairtrade products. See Kleiner, supra note 57.

68. See id.

69. See, e.g., Tara Bozick, Business Coming to Fort Monroe: Liberty-Source to Employ Almost 600 Skilled Members of Military Community, DAILY PRESS (Newport News, Va.), July 17, 2014, at A1, 2014 WLNR 19418565; Tara Bozick, Fort Monroe Business Lands AOL Contract, DAILY PRESS (Newport News, Va.), Nov. 12, 2014, at A3, 2014 WLNR 31788447; Robert Brauchle, More Incentives Possible for Business Coming to Fort Monroe: Hampton, Authority, State Might Offer Combined \$1 Million, DAILY PrESS (Newport News, Va.), Aug. 13, 2014, at A8, 2014 WLNR 22176673; MaRhonda Echols, Fort Monroe to Get 600 New Jobs, DAILY PRESS, (Newport News, Va.) July 20, 2014, at A4, 2014 WLNR 20626121.

70. Bozick, Business Coming to Fort Monroe, supra note 69.

71. For-Profit Bank Becomes First Benefit Corporation Bank in U.S., PR WEB (Apr. 4, 2016), http://www.prweb.com/pdfdownload/13301237.pdf.

72. Id. 


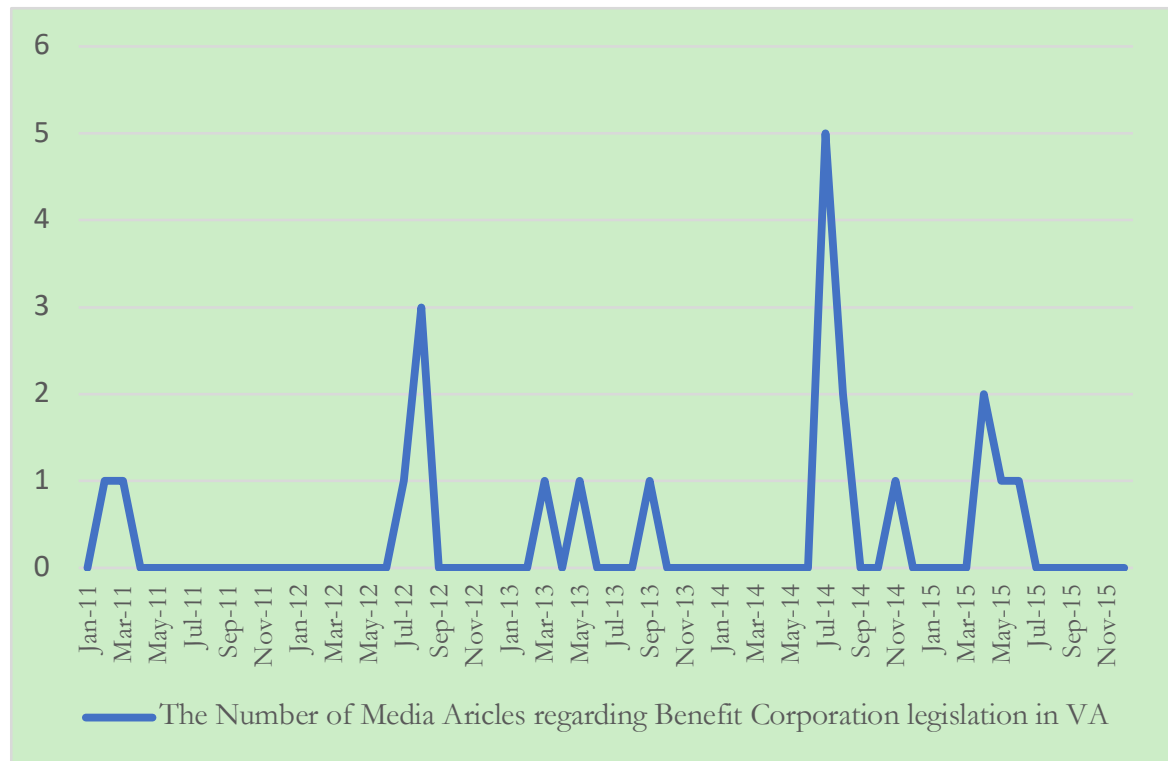

Figure 1: Number of Media Articles Referencing Benefit Corporation in Virginia, January 2011-January 2016 73

As evident in Virginia's experience, passing a benefit corporation statute led to dozens of firms either changing their pre-existing corporate form, or filing as a benefit corporation at the time of creation. These firms have had myriad impacts on the surrounding communities prompting new economic development and the promotion of diverse social goods. We next turn to Connecticut, which had a far different experience in passing its own benefit corporation legislation.

\section{Connecticut}

As with Virginia, it is first helpful to understand the context of Connecticut's economic performance, since this became a driver of the benefit corporation debate that happened in the state. On the one hand, the state contributed over $\$ 260$ billion to the U.S. GDP in 2016,74 which made Connecticut the second largest economy in the New England area and represented 1.4 percent of total U.S. GDP. ${ }^{75}$ Its economic performance since then has been generally positive, but still is a story of extremes with

73. This chart is based on Westlaw's "Virginia News" database. The research covered media articles containing the phrase "Benefit Corporation" from January 2011 to January 2016.

74. Table 3, Current-Dollar Gross Domestic Product (GDP) by State, 2016:Q1-2017:Q1, supra note 28.

75. The largest economy in the New England is Massachusetts, which was responsible for more than $\$ 500$ billion towards the U.S. GDP from 2016-2017. See id. 
quarterly growth ranging from 4.4 percent in early 2017 to zero in $2016 .{ }^{76}$ Connecticut's economic data shows that retail trade, finance and insurance, and utilities were the most recessive sectors from 2016 to 2017. These sectors negatively contributed to Connecticut GDP's percent change in 2016. ${ }^{77}$ The wholesale trade sector was the most important for Connecticut's economic growth; ${ }^{78}$ durable-goods and nondurable-goods manufacturing were the second and third fastest-growing sectors. ${ }^{79}$

But these figures in many ways miss the bigger point. The state of Connecticut was severely impacted by the 2008 financial crisis, 80 and still struggles; in 2017 quarter 1 Connecticut's GDP growth rate was slower than the overall nation. ${ }^{81}$ According to data released by the Bureau of Economic Analysis in June 2015, Connecticut's GDP grew by 0.6 percent from 2013 to 2014, while the country grew 2.2 percent in 2014 after increasing 1.9 percent in 2013. 82 New York's GDP grew by 2.5 percent, while Massachusetts and New Hampshire both saw GDP growth of 2.3 percent. ${ }^{83}$ These economic statistics informed the debate surrounding what was to become Connecticut's benefit corporation statute.

\section{The History of the Benefit Corporation Legislation Campaign in Connecticut}

In 2014, "Connecticut became the 26th state to give social enterprises deemed 'benefit corporations' - special designation and the first to allow 'BCorporations' to maintain their status in the event of ownership's changing hands." ${ }^{4}$ The Connecticut Benefit Legislation S.B. 23, "An Act Concerning Benefit Corporations and Encouraging Social Enterprise" (the Act), was

76. See Stephen Singer, In Connecticut, Economic Growth Surges, but Skepticism Persists, HARTFORD COURANT (Jan. 24, 2018), https://www.courant.com/business/hc-biz-connecticut-economy20180124-story.html.

77. Table 2, Contributions to Percent Change in Real Gross Domestic Product (GDP) by State, 2016:Q42017:Q1, BUREAU ECON. ANALYSIS (July 26, 2017), https://www.bea.gov/news/2017/grossdomestic-product-state-1st-quarter-2017 (select tab "Related Materials," then select "Release Tables Only" to open Excel document); see id. (specifying 21 sectors from Agriculture to Government). 2017).

78. See id. (wholesale trade contributed 33\% to Connecticut GDP's percent change from 2016-

79. See id.

80. See, e.g., Soncia Coleman et al., Effects of Foreclosure Crisis in Connecticut, OFF. LEGIS. RES. REP. (Feb. 16, 2010), https://www.cga.ct.gov/2010/rpt/2010-R-0019.htm (the number of Lis pendens fillings were nearly doubled from 2006 to 2009); Rute Pinho, Impact of Financial Crisis on State's Travel and Tourism Industry, OFF. LEGIS. RES. REP. (Jan. 22, 2010), https://www.cga.ct.gov/2010/rpt/2010R-0011.htm.

81. Table 1, Percent Change in Real Gross Domestic Product (GDP) by State, 2016:Q1-2017:Q1, supra note 26 (Connecticut's 2017:Q1 GDP percent change ranked 37th overall).

82. See id.

83. Stephen Busemeyer, Connecticut's GDP Growth Among Slowest In Nation, HARTFORD COURANT, (June 10, 2015), http://tronc-hartford-courant-prod.origin.arcpublishing.com/news/connecticut/hcconnecticuts-gdp-slow-growth-20150610-story.html.

84. Zach Melvin, Nonprofit Gets $\$ 50 K$ Grant Startup Accelerator Program, HARTFORD COURANT, Aug. 12, 2015, 2015 WLNR 23821939. 
introduced to the Joint Committee on Commerce on February 7, 2014, and became effective on October 1, $2014 .{ }^{85}$ Unlike in Virginia, the campaign for this bill was far from easy. Before the final successful vote on S.B. 23, the supporters of the Connecticut benefit corporation legislation failed twice, highlighting the importance of stakeholder engagement in pushing this issue forward, as unpacked further in Part V.

The first Connecticut benefit corporation bill, ${ }^{86}$ H.B. 5490 (Conn. 2012), was introduced on March 8, 2012; however, it was not reported out of committee because of opposition from the Connecticut Bar Association and individual attorneys. ${ }^{87}$ The state bar business law section lodged several reasons for its opposition to the proposed legislation, ${ }^{88}$ related primarily to traditional corporate governance issues of director responsibilities and shareholder rights. It objected to the additional factors beyond shareholder interests that boards of directors were required to consider in their decisions, ${ }^{89}$ the potentially expensive threat and negative impact of benefit enforcement proceedings on boards of directors, and the "burdensome" annual benefit report. ${ }^{90}$ However, the bar committee supported the general concept of benefit corporations, and offered to work with legislators to produce an acceptable statute. ${ }^{91}$

The Benefit Corporation bill was reintroduced to the Connecticut General Assembly again on February 7, 2013, ${ }^{22}$ but it failed for the second straight year. ${ }^{93}$ There was no public opposition to the bill this time, however. Rather, "time ran out for a vote in the state Senate," 94 implying a lack of priority. The bill was put on the fast track the following year, paving the way for the passage of S.B. 23 in 2014. ${ }^{25}$ S.B. 23 was introduced by Senator Donald E. Williams, Senator Martin M. Looney, Representative J. Brendan

85. S.B. 23, 2014 Gen. Assemb., Feb. Sess. (Conn. 2014).

86. H.B. 5490, 2012 Gen. Assemb., Feb. Sess. (Conn. 2012).

87. See Hearing on H.B. 5490, An Act Concerning the Establishment of Benefit Corporations, Before the Judiciary Comm., 2012 Gen. Assemb., Feb. Sess. (Conn. 2012) (statement of John M. Lawrence, Vice Chair of the Business Law Section, Connecticut Bar Association) [hereinafter Lawrence statement]; Hearing on H.B. 5490, An Act Concerning the Establishment of Benefit Corporations, Before the Judiciary Comm., 2012 Gen. Assemb., Feb. Sess. (Conn. 2012) (statement of John M. Horak, Partner, Reid \& Reige).

88. See Lawrence statement, supra note 87.

89. Id.

90. Id.

91. Id.; Hearing on H.B. 2650 Before the Honorable Lance Kleeb and Members of the Comm. on Commerce, Labor and Economic Development, 2014 Leg., Reg. Sess. (Kan. 2014) (statement of Joseph N. Molina, Kansas Bar Association); Mark Loewenstein \& Herrick K. Lidstone, Jr., Benefit Corporations in Colorado, COLO. B. Ass'N BUS. L. NEWSLETTER (Jan. 2013), https:/ / tinyurl.com/ya3dbvee (with the support of the Colorado Bar Association, a number of attorneys opposed the strict mandates and marketing aspects of the proposed legislation in 2011 and 2012).

92. H.B. 6356, 2013 Gen. Assemb., Jan. Sess. (Conn. 2013).

93. See Dan Haar, B is for Benefit: Bill on Track to Ease Legalities for Commerce Aimed at Public Good, HARTFORD COURANT, Jan. 15, 2014, 2014 WLNR 1386354.

94. Id.

95. Id. 
Sharkey, and Representative Joe Aresimowicz, and was co-sponsored by fifteen representatives and nine senators. ${ }^{96}$ On March 11, 2014, the Connecticut Commerce Committee unanimously passed the bill. ${ }^{97}$ It received thirty-four to four votes in the Connecticut Judiciary Committee on April 1, 2014,98 and secured the backing of forty-five out of forty-eight voters in Connecticut Appropriations Committee on April 24, 2014.9

S.B. 23 included several amendments to earlier proposals. First, the new bill followed the Model Act created by B Lab by including a "Benefit Director" and a "Benefit Officer" with specific powers, duties, rights, and immunities, ${ }^{100}$ and are separate from the regular directors and officers. ${ }^{101}$ These new designations can lessen the impact on general directors and therefore addressed one of the concerns stated by the Vice Chair of the Business Law Section of Connecticut Bar Association that the dual interests would be too burdensome. ${ }^{102}$ Second, S.B. 23 narrowed and specified the terms of the benefit enforcement proceeding so that only certain groups of directors or shareholders could bring a derivative action; this amendment answered another concern by the state bar association that the right to bring an enforcement proceeding was too tenuous. ${ }^{103}$ In fact, the benefit director, benefit officer, and the limited right to bring a benefit enforcement proceeding, are all in the Model Act. ${ }^{104}$ Third, the final bill added an appraisal right clause as a protection for the minority shareholders who opposed the conversion to a benefit corporation, ${ }^{105}$ which was missing in the original bill and was also mentioned in a local bar association's opposing testimony. ${ }^{106}$ Aside from these key amendments, S.B. 23 implemented a

96. S.B. 23, 2014 Gen. Assemb., Feb. Sess. (Conn. 2014).

97. Commerce Comm. Vote Tally Sheet S.B. 23, 2014 Gen. Assemb., Feb. Sess. (Conn. 2014), https://www.cga.ct.gov/2014/TS/s/pdf/2014SB-00023-R00CE-CV2-TS.pdf.

98. Id.

99. Appropriations Comm. Vote Tally Sheet S.B. 23, 2014 Gen. Assemb., Feb. Sess. (Conn. 2014), https://www.cga.ct.gov/2014/TS/s/pdf/2014SB-00023-R00APP-CV86-TS.pdf.

100. S.B. 23, 2014 Gen. Assemb., Feb. Sess. \S 10, 12 (Conn. 2014); see also The Model Legislation, BENEFIT CORP., https://benefitcorp.net/attorneys/model-legislation (last visited May 31, 2020); Model Benefit Corporation Legislation, BENEFIT CORP. 3 (Apr. 17, 2017), https://benefitcorp.net/ sites/default/files/Model\%20benefit $\% 20$ corp\%20legislation\%20_4_17_17.pdf [hereinafter Model Act].

101. See id. $\iint 9,11$.

102. See Lawrence statement, supra note 87.

103. S.B. 23, 2014 Gen. Assemb., Feb. Sess. \$S 10(b), 12, 13(c) (Conn. 2014).

104. See id. $\iint 10,12,16$; Lawrence statement, supra note 87 (" $[T]$ he benefit enforcement proceeding ... may even be brought by a director who has no financial interest in the corporation.”).

105. See Model Act, supra note 100, Appendix A, $\int \mathbb{S} 302$ (Benefit Director), 304 (Benefit Officer), 305 (Right of Action).

106. See Lawrence statement, supra note 87 ("[A] regular corporation could be converted to a benefit corporation by vote of two-thirds of the shareholders without any form of protection ... for the minority shareholders who oppose such a change.”). 
more flexible requirement regarding the annual benefit report to satisfy the demand from the local bar association. ${ }^{107}$

\section{Stakeholder Advocacy for the Connecticut Benefit Corporation Legislation}

All told, twenty-three organizations and individuals testified before the Connecticut Commerce Committee in support of the legislation. ${ }^{108}$ Nearly all of the bill's supporters believed that its passage would spur Connecticut's economy and create more job opportunities. ${ }^{109}$ Leslie Krumholz, the founder of GoodStreets, an online consumer review site of local businesses, for example, stated "a bill like S.B. 23 can provide exactly what we need to create thriving businesses that will not only produce profits and create more jobs but will also provide a lasting impact to our state in the form of a general public benefit." 110 In the midst of a slow recovery from a severe economic downturn, it seems that there was a re-thinking of the relationship between business and society.

Despite pressure to spur economic growth and job opportunities, a nonprofit organization promoting social entrepreneurship, reSET, led the three years' long Connecticut movement critical to passing the state's benefit corporation bill. ${ }^{111}$ reSET generally provides resources and incubator offices for social enterprises, like A Happy Life, ${ }^{112}$ in their Hartford office. ${ }^{113}$ More specifically, reSET worked to gain the Connecticut Governor's support for the benefit corporation legislation after it failed for the second straight

107. According to S.B. 23, the disclosure of the information regarding director's compensation and any financial, confidential, or proprietary information in the benefit report is optional. However, the omission of such information requires permission from the third-party standard adopted by the benefit corporation in H.B. 5490. Compare S.B. 23, 2014 Gen. Assemb., Feb. Sess. \15(b-c) (Conn. 2014) with S.B. 23, 2014 Gen. Assemb., Feb. Sess. \11(c) (Conn. 2014).

108. See An Act Concerning Benefit Corporations and Encouraging Social Enterprise: Hearing on S.B. 23 Before the Commerce Comm., 2014 Gen. Assemb., Feb. Sess. (Conn. 2014).

109. See An Act Concerning Benefit Corporations and Encouraging Social Enterprise: Hearing on S.B. 23 Before the Commerce Comm., 2014 Gen. Assemb., Feb. Sess. (Conn. 2014) (statement of Kate Emery, Chief Executive Officer, The Walker Group) [hereinafter Emery statement] (testifying that the Act will provide an easy, inexpensive way for other business to set up as a social enterprise and thereby create jobs); see also An Act Concerning Benefit Corporations and Encouraging Social Enterprise: Hearing on S.B. 23 Before the Commerce Comm., 2014 Gen. Assemb., Feb. Sess. (Conn. 2014) (statement of Jeff Shaw, Director of Public Policy, Connecticut Association of Nonprofits) ("This proposal will provide new opportunities to address service needs and drive economic growth by bringing new jobs to Connecticut and making our state an attractive home for forward-thinking individuals, policymakers, and companies.").

110. An Act Concerning Benefit Corporations and Encouraging Social Enterprise: Hearing on S.B. 23 Before the Commerce Comm., 2014 Gen. Assemb., Feb. Sess. (Conn. 2014) (statement of Leslie Krumholz, cofounder, GoodStreets).

111. See Dan Haar, Reset Celebrates Legislative Win Hartford, HARTFOrd COURANT, May 10, 2014 , 2014 WLNR 12750158 ("The organization successfully lobbied for the legislation's passage after three years of trying.").

112. See Haar, supra note 93.

113. See Haar, supra note 111. 
year. ${ }^{114}$ The motivation behind reSET's tireless efforts to promote the bill echoed the state's need for job opportunities; Kate Emery, ${ }^{115}$ the founder of reSET and "godmother" of Connecticut social enterprise movement, pointed out that the passage of benefit corporation legislation could attract "serious social entrepreneurs to Hartford."116

Other stakeholders also shared the vision for benefit corporations supporting social enterprises. The American Association of Retired Persons (AARP)-Connecticut, for example, supported the benefit corporation legislation because it saw social enterprises as creating valuable opportunities for "Encore Entrepreneurs," 117 people over fifty years old seeking meaningful second careers. ${ }^{118}$ In addition to the AARP, the Connecticut Veterans' Chamber of Commerce supported the bill. It believed that the benefit corporation option would attract entrepreneurial veterans to the state given the propensity of veterans to have a strong "sense of service," and the ability for social enterprises to prosper under this corporate form. ${ }^{119}$

As discussed in Part II, social enterprises can be defined in various ways, but ultimately, the confluence between social good and business profit provided strong support for Connecticut's benefit corporation legislation. An information technology company CEO, for example, described the difficulty the for-profit company experienced when it tried to choose a legal form that would support the founders' intent to both earn a profit and "make a positive social impact." 120 The company spent "tens of thousands of dollars in legal fees and time creating a complex legal structure"121 to accomplish the same result as compared to the "easy inexpensive way" in which the benefit corporation accomplished the same result. ${ }^{122}$ This same calculus may inform the decision-making of a variety of firms considering whether to make the switch from traditional corporate forms to benefit corporations.

114. See Haar, supra note 93 (“Gov. Dannel P. Malloy showed up at reSET’s Pratt Street office Tuesday to deliver his support ....”).

115. Christine Stuart, 20 Connecticut Social Entrepreneurs Convert Their Companies to Benefit Corporations, CTNEWSJUNKIE.COM (Oct. 1, 2014, 3:50 PM), https://tinyurl.com/ybejmq22.

116. Haar, supra note 111.

117. See An Act Concerning Benefit Corporations and Encouraging Social Enterprise: Hearing on S.B. 23 Before the Commerce Comm., 2014 Gen. Assemb., Feb. Sess. (Conn. 2014) (statement of Robert Romasco, President, American Association of Retired Persons Connecticut).

118. See id.

119. See An Act Concerning Benefit Corporations and Encouraging Social Enterprise: Hearing on S.B. 23 Before the Commerce Comm., 2014 Gen. Assemb., Feb. Sess. (Conn. 2014) (statement of Dawn McDaniel, Executive Vice President, Connecticut Veterans Chamber of Commerce) (arguing that social enterprise would increase opportunity and options for veteran business ownership).

120. Emery statement, supra note 109.

121. Id.

122. Id. 


\section{Local Impact of Benefit Corporation Legislation}

Twenty companies immediately instituted the legal change to become a benefit corporation when the legislation became effective. ${ }^{123}$ Subsequently, reSET, the aforementioned main supporter ${ }^{124}$ behind Connecticut's Benefit Corporation legislation, ${ }^{125}$ was awarded $\$ 50,000$ by the U.S. Small Business Administration to use its startup accelerator program exclusively to help social entrepreneurs-including benefit corporations in their formation stage-by providing "access to expert advisers, mentors and funding sources, as well as reSET's job board and internship platform."126

According to $\mathrm{B} \mathrm{Lab}^{127}$ and the Connecticut Secretary of the State's Business databases, ${ }^{128}$ there were thirty-nine active benefit corporations in Connecticut as of 2016. ${ }^{129}$ Twenty-seven Connecticut corporations filed benefit corporation registration/conversion papers in 2014, and another sixteen corporations filed in 2015. ${ }^{130}$ Among those forty-three benefit corporations, however, four companies were dissolved by mid-2016. ${ }^{131}$

Connecticut media interests in the Benefit Corporation legislation reflects state legislative actions, which may indicate that broader civil society engagement was tied to the legal debate. From May 18, 2013 to August 12, 2015, there were a total of twenty-two articles covering the phrase "Benefit Corporation" that had been published in leading local newspapers such as Harfford Courant, Connecticut Post, and Herald (New Britain, CT). However, there were no reports about the Benefit Corporation in any Connecticut news during periods of legislative inaction. Similarly, there are only three articles about the term Benefit Corporation that were published in local newspapers three months after Connecticut's benefit corporation legislation came into effect on October 1, 2014, as shown in Figure 2.

123. See Stuart, supra note 115.

124. Id.

125. Id.

126. See Melvin, supra note 84.

127. B Lab makes its "best effort to create an accurate accounting of benefit corps and is inclusive of all data collated by B Lab from state agency reports. Many states do not currently track the names or number of benefit corporations. B Lab continuously collects this data, however each state has [a] different level of reporting capabilities." Find a Benefit Corp, BENEFIT CORP., https://tinyurl.com/ ydal6azz (last visited Jan. 24, 2016).

128. Connecticut Business Registry Search, CONN. SECRETARY ST., http://www.concordsots.ct.gov/CONCORD/online?sn=PublicInquiry\&eid=9740 (last visited Oct. 29, 2017).

129. See Find a Benefit Corp, supra note 127.

130. The Connecticut Secretary of the State Business search database does not allow searches by entity type. We gathered a list of benefit corporations that converted or incorporated in Connecticut on B Lab's website, which were then cross-referenced with the B Lab list and Connecticut Secretary of the State Business search database.

131. See id. 


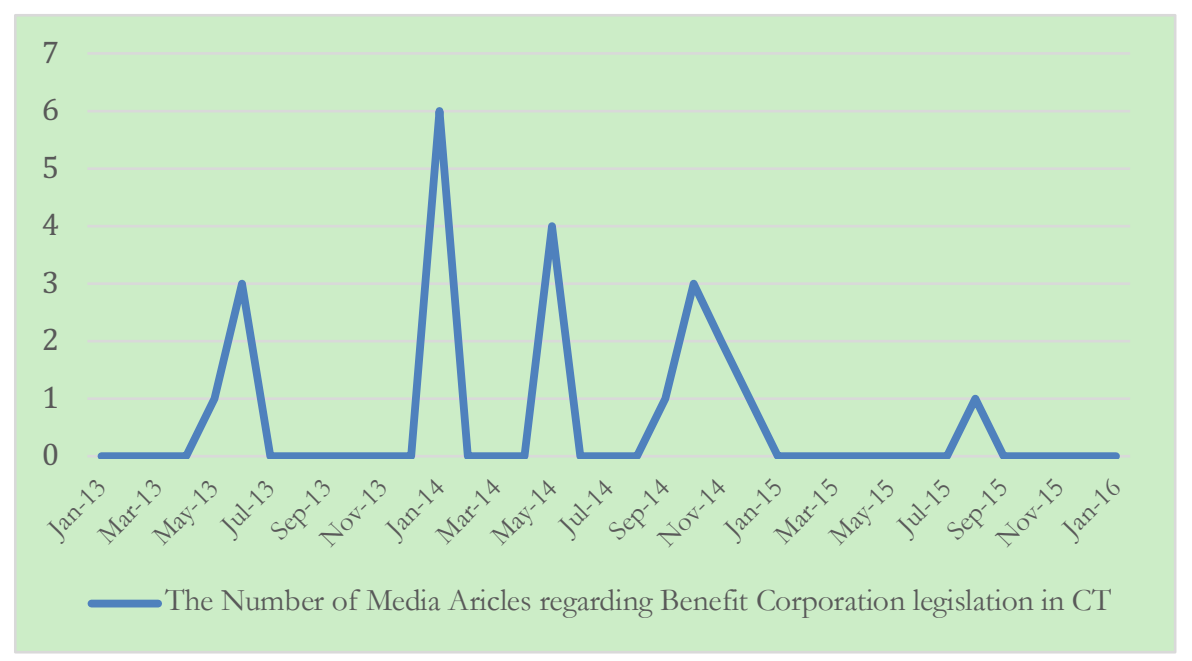

Figure 2: Number of Media Articles Referencing Benefit Corporation in Connecticut, January 2013-January 2016 132

As is apparent in Figure 2, when H.B. 6356, the second benefit corporation bill, ${ }^{133}$ was introduced in February 2013, media attention hit its first peak. Then, S.B. 23 was offered in January 2014, passed the House and Senate in March and April respectively, and became effective in October 2014, after which time media attention declined. These data highlight the extent to which the public was engaged at various points in the passage of Connecticut's benefit corporation legislation, which we hypothesize may be correlated with higher degrees of uptake, as is discussed further in Part IV.

\section{Delaware}

According to data released by the Bureau of Economic Analysis in July 2017,134 Delaware's GDP growth rate was 0.3 percent from 2015-2016.135 The state contributed more than $\$ 69$ billion to U.S. GDP in 2016, which made Delaware the smallest economy in the Northeast, bringing with it a different fiscal starting point than Connecticut. ${ }^{136}$ But despite its relatively small economy, Delaware is remarkable because it serves as the place of incorporation for "more than 50 percent of all U.S. publicly-traded

132. This chart is based on Westlaw "Connecticut News" database. The research covered the phrase "benefit corporation" from January 2013 to January 2016.

133. The first benefit corporation bill, H.B. 5490, was not reported out of the committee. That may explain why there was no media article about this bill in 2012. See supra note 87 and accompanying text.

134. Gross Domestic Product by State: 1st Quarter 2017, supra note 25.

135. Table 1, Percent Change in Real Gross Domestic Product (GDP) by State, 2016:Q1-2017:Q1, supra note 26.

136. Table 3, Current-Dollar Gross Domestic Product (GDP) by State, 2016:Q1-2017:Q1, supra note 28. 
companies and 63 percent of the Fortune 500."137 In 2013, approximately eighty-five percent of U.S. Initial Public Offerings (IPOs) involved Delaware corporations. ${ }^{138}$ It is beyond dispute that Delaware is the most significant U.S. state regarding corporate law, ${ }^{139}$ and Delaware corporate statutes have tremendous influence among institutional investors, corporate managers, and financial intermediaries who raise capital. ${ }^{140}$ Therefore, the story of Delaware's benefit corporation legislation serves as an important data point for other U.S. states and foreign nations considering similar steps.

\section{The History of the Benefit Corporation Legislation Campaign in Delaware}

On July 17, 2013, Delaware became the nineteenth state to pass a statute recognizing the benefit corporation as a legal entity. ${ }^{141}$ Senate Bill 47 of the 147th General Assembly, "An Act to Amend Title 8 of the Delaware Code Relating to the General Corporation Law," was introduced to the Delaware Senate Small Business Committee on April 18, 2013. The bill was passed by the Delaware House of Representatives on June 13, 2013, and was signed into law by Governor Jack Markell on July 17, 2013.142 The primary sponsor of this bill was Democratic Senator David Sokola, and the bill was cosponsored by three senators and six representatives. ${ }^{143}$ S.B. 47 passed quickly and was widely supported by legislators in both the House and Senate, receiving twenty positive votes of the twenty-one potential votes in the Delaware State Senate. ${ }^{144}$ According to the House Committee Report, the bill passed with such overwhelming support because the Economic Development, Banking, Insurance, and Commerce Committee found that

137. Matthew W. Bower, When it Comes to Incorporating Your Startup, Why Delaware?!?, NAT'L L. REV. (Feb. 11, 2015), https://tinyurl.com/y75fvfz5.

138. Jeffrey R. Wolters, Delaware Insider: Delaware Law Pitfalls in IPOs, Bus. L. TODAY 33 (Nov. 2013), https://tinyurl.com/y8mvazfo.

139. See, e.g., William J. Carney et al., Lawyers, Ignorance, and the Dominance of Delaware Corporate Law, 2 Harv. Bus. L. Rev. 123, 125 (2012); Alicia E. Plerhoples, Delaware Public Benefit Corporations 90 Days Out: Who's Opting In?, 14 U.C. DAVIS BUS. L.J. 247, 248-49 (2014); Omari Scott Simmons, Branding the Small Wonder: Delaware's Dominance and the Market for Corporate Law, 42 U. RICH. L. REV. 1129, 1129 n.3 (2008).

140. Brian J. Broughman et al., Delaware Law as Lingua Franca: Evidence from VC-backed Startups (Harvard John M. Olin Ctr. for Law, Econ., \& Bus., Discussion Paper No. 721, 2012), http://www.law.harvard.edu/programs/olin_center/papers/pdf/Fried_et\%20al_721.pdf (“[F]irms wishing to sell their shares to mostly out-of-state public investors through an IPO may also choose Delaware law in part to provide a common language to their shareholders."); Steven Lipin, Firms Incorporated in Delaware Are Valued More By Investors, WALL ST. J. (Feb. 28, 2000), https://www.wsj.com/articles/SB951694281741477590; Table 2, Contribution to Percent Change in Real GDP by State, 2013-2014, supra note 32.

141. S.B. 47, 147th Gen. Assemb., Reg. Sess. (Del. 2013).

142. Id.

143. Id. (Sens. Henry, Lavelle, Townsend; Reps. M. Smith, Walker, Baumbach, Q. Johnson, Bennett, Peterman).

144. S. Voting Rep. S.B. 47, 147th Gen. Assemb., Reg. Sess. (Del. 2013) (twenty Yes and one Not Voting). 
creating public benefit corporations might incentivize new corporations to form in Delaware. ${ }^{145}$ However, this consensus is only a small part of the story; as described further in Part $\operatorname{III}(\mathrm{C})(2)$, prior to the law's enactment there was extended debate over four years about the wisdom to allow the creation of a benefit corporation form, and subsequent amendments to the law reflect the continuation of the controversy.

Unlike any other state to pass a benefit corporation law, Delaware's version was the first to vary significantly from the Model Benefit Corporation Legislation created by B Lab. Although portions were subsequently deleted or amended, Delaware's first benefit corporation law included four variations of this new corporate form. First, Delaware corporations were required to state that they were public benefit corporations in their certificates of incorporation, 146 and the name of the company was required to contain "public benefit corporation," "PBC," or "P.B.C." 147 Second, Delaware public benefit corporations were required to state a specific public benefit, defined as "a positive effect (or reduction of negative effects) on one or more categories of persons, entities, communities or interests (other than stockholders in their capacities as stockholders)." 148 The Model Legislation, on the other hand, makes disclosure of the specific public benefit purpose optional, compared to the required general public benefit. ${ }^{149}$ Third, Delaware's statute set a very high shareholder approval vote requirement as compared to the Model Law;150 ninety percent of the outstanding shares of each class of stock of an existing corporation are required to convert into a Delaware public benefit corporation, 151 whereas the Model Law only requires a two-thirds majority. ${ }^{152}$ Lastly, unlike the Model Law's requirement of an annual assessment by a third party standard, to determine the extent to which a company successfully created and implemented a specific public benefit, 153

145. H.R. Comm. On ECON. Dev., Banking, Ins., \& Commerce, Delaware CommitTeE REPORT, 147th Gen. Assemb., Reg. Sess. (2013).

146. S.B. 47, 147th Gen. Assemb., Reg. Sess. S§ 362(a), (c) (Del. 2013).

147. Steven H. Schulman, Delaware Public Benefit Corporations: A Brief Introduction, AKIN GUMP: AG DEAL DiARY (Nov. 14, 2013), https://www.akingump.com/en/experience/practices/corporate/agdeal-diary/delaware-public-benefit-corporations-a-brief-introduction.html.

148. S.B. 47, 147th Gen. Assemb., Reg. Sess. \362(b) (Del. 2013) (“including, but not limited to, effects of an artistic, charitable, cultural, economic, educational, environmental, literary, medical, religious, scientific or technological nature").

149. Model Act, supra note 100, $\$ 201$ (b) ("The articles of incorporation of a benefit corporation may identify one or more specific public benefits that it is the purpose of the benefit corporation to create in addition to its [general public benefit purpose].”).

150. Schulman, supra note 147.

151. S.B. 47, 147th Gen. Assemb., Reg. Sess. \ 363 (Del. 2013).

152. See Model Act, supra note 100, \$104(a) ("An existing business corporation may become a benefit corporation ... by amending its articles of incorporation ... . [i]n order to be effective, the amendment must be adopted by at least the minimum status vote.").

153. Id. $₫ 401$. 
the Delaware statute requires only a biannual statement to be given to stockholders with an optional third party standard. ${ }^{154}$

As was quickly noted, however, "publicly traded entities, even those with identifiable benefits to the public, may find the $90 \%$ stockholder approval threshold in Delaware too high a bar." 155 In order to accommodate the need for more reasonable restrictions for a corporation to become a public benefit corporation, ${ }^{156}$ the Corporation Law Council of the Delaware State Bar Association announced proposed amendments to the Delaware General Corporation Law on April 2, 2015.157 Those amendments were a part of Senate Bill 75, ${ }^{158}$ which was passed by the Senate unanimously and received forty positive of the forty-one votes in the House on June 11, 2015.159 S.B. 75 was signed into law by Governor Markell on June 24, $2015,{ }^{160}$ making several important changes to provisions of the Delaware benefit corporation statute that hindered implementation. ${ }^{161}$ First, the original approval requirement of a ninety percent vote of all outstanding shares on an existing company to become a public benefit corporation was amended to two-thirds of all outstanding shares entitled to vote. ${ }^{162}$ Second, the mandatory naming requirement was made optional. ${ }^{163}$ S.B. 75 also added a "'market out' to the appraisal provisions available to a stockholder of a corporation that merges or converts into a public benefit corporation."164 The new market out exception for Delaware public benefit corporations is similar to the exception that applies to appraisal rights generally under section 262.165 Under the 2015 amendments, the appraisal rights are not absolute when a corporation converts to a public benefit corporation. ${ }^{166}$

Unlike the 2013 statute, neither the Senate nor the House stated the purpose of the amendments in their Committee Reports. ${ }^{167}$ From the plain

154. S.B. 47, 147th Gen. Assemb., Reg. Sess. \$ 366 (Del. 2013).

155. Schulman, supra note 147.

156. Gregory P. Williams, Amendments to the DGCL, HARV. L. SCH. F. ON CORP. GOVERNANCE \& FIN. REG. (June 30, 2015), https://corpgov.law.harvard.edu/2015/06/30/amendments-to-the$\mathrm{dgcl} /$.

157. Frederick H. Alexander, Amendments to the DGCL Remove Obstacles to Adoption of Public Benefit Status, BLOOMBERG BNA (May 1, 2015), https://www.mnat.com/assets/attachments/253.pdf.

158. S.B. 75, 148th Gen. Assemb., 1st Reg. Sess. (Del. 2015).

159. H.R. Voting Rep. S.B. 75, 148th Gen. Assemb., Reg. Sess. (Del. 2015).

160. S.B. 75, 148th Gen. Assemb., 1st Reg. Sess. (Del. 2015).

161. See Alexander, supra note 157.

162. S.B. 75, 148th Gen. Assemb., 1st Reg. Sess. \ 12 (Del. 2015).

163. See id. $\$ 11$.

164. John Marsalek, 2015 Amendments to the Delaware General Corporation Law, DORSEY \& WHITNEY LLP (June 29, 2015), http:/ / tinyurl.com/gqhq24w.

165. Williams, supra note 156.

166. Id.

167. The House of Representatives only mentioned that this bill was meant to prevent "corporations from adopting bylaws that would force the loser of a stakeholder lawsuit to pay the corporate legal fees." See COMm. ON Judiciary, Delaware COMMiTTEE REPORT ON S.B. 75, 148th Gen. Assemb., 1st Reg. Sess. (Del. 2015). 
text, the amendments appear to make entrepreneurs and investors more comfortable to incorporate as or convert their companies into public benefit corporations. ${ }^{168}$ Although the structure of the PBC statute remained largely intact, both public and private corporations have a clearer path to conversion. ${ }^{169}$

\section{Stakeholder Advocacy for Delaware Benefit Corporation Legislation}

Passage of benefit corporation legislation in Delaware was a lengthy and contentious process beginning in 2009. ${ }^{170}$ At that time, there were concerns about the innovative legal designation among many key players, such as Frederick Alexander, the chair of the Delaware Bar's Corporations Law Council. ${ }^{171}$ One key argument was that an investor would not want to invest in a company that did not consider serving shareholders to be its primary purpose. ${ }^{172}$ In September 2012, B Lab organized a meeting at which twelve benefit corporation executives and several of their investors spoke with the Delaware Secretary of State Jeffrey Bullock, along with the Chancellor of the Court of Chancery Leo Strine, and dozens of attorneys in the Delaware Bar's Corporations Law Council. ${ }^{173}$ This meeting was critical to advocacy efforts since the underlying philosophy of Delaware corporate law "is to enable managers and investors to order their internal financial affairs in ways that make sense to them." 174 The meeting provided a channel for information exchange between advocates and corporate investors. As a result, lawmakers were more aware that public firms and institutional investors ${ }^{175}$ cared about their social good in addition to their stock prices, and made investments with "an eye toward their societal impact."176

In addition to B Lab's coordination and professional leadership, Chief Justice Strine provided essential support by promoting this new corporate form in several law review articles. ${ }^{177}$ Specifically, Chief Justice Strine argued for Delaware public benefit corporation primacy for directors and officers

168. Alexander, supra note 157.

169. Id.

170. Katie Gilbert, Delaware Overcomes its Qualms and Advances B Corps Law, INSTITUTIONAL INV., July 3, 2013, 2013 WLNR 15844875.

171. See id.; see also Michael B. Dorff, Why Public Benefit Corporations?, 42 DEL. J. CORP. L. 77 (2017).

172. See Gilbert, supra note 170.

173. See id.

174. See id.

175. CEO Mark Zuckerberg echoed the thinking behind the benefit-corporation model in a letter to prospective shareholders before Facebook's IPO. See id.

176. See id.

177. See, e.g., Leo E. Strine, Jr., Making it Easier for Directors to "Do the Right Thing"?, 4 HARV. BUS. L. REV. 235, 235 (2014). 
who wish to do good for stockholders, society, and the environment, ${ }^{178}$ by responding to opponents ${ }^{179}$ such as Charles Elson who argued that this legislation did not make sense because investors would lose recourse. 180 Chief Justice Strine's support was pivotal for Delaware's benefit corporation statute because of his position in one of the most influential business courts in the world 181 and his sincere belief in the benefit corporation movement.

The advocacy undergirding the Delaware campaign was distinct from the situation in Connecticut. The Delaware State administration's backing for benefit corporation legislation and their active advocacy were indispensable in its eventual passage. On the other hand, the Governor and the Secretary of State did not initiate the campaign and were unconvinced that their state was ready for this legal designation until the meeting organized by B Lab. ${ }^{182}$ According to the statements from the Delaware Governor's office, ${ }^{183}$ the state's commitment to lead in U.S. corporate law and the peer pressure from nearly half of the states who already adopted benefit corporation legislation were the driving forces behind the office's enthusiasm for Delaware PBC advocacy. ${ }^{184}$

In summary, the unanimous passage of the Delaware benefit corporation statute, and its subsequent amendments, was ultimately the result of collaborative efforts of Delaware Governor Markell, the Delaware State Bar Association, the Delaware Court of Chancery, the Secretary of State, B Lab, and grassroots supporters. Among all these stakeholders, B Lab's professional leadership and experiences in benefit corporation advocacy in other states played a crucial role in the success of the advocacy efforts for the Delaware benefit corporation legislation.

178. John Montgomery, Why Does the Delaware Public Benefit Corporation Matter to Silicon Valley?, GREAT FROM START (July 9, 2015), http://www.greatfromthestart.com/why-does-the-delawarepublic-benefit-corporation-matter-to-silicon-valley/.

179. Strine, supra note 177, at 244 ("The Delaware statute also creates incentives for the creation of objectives and standards that allow for directors to be held accountable for managing the corporation in a sustainable and responsible manner.").

180. See Public Benefits Firms Mulled, NEws J. (Wilmington, Del.), Apr. 21, 2013, 2013 WLNR 9782796.

181. See id.; Leo E. Strine, Jr., The Dangers of Denial: The Need for a Clear-Eyed Understanding of the Power and Accountability Structure Established by the Delaware General Corporation Law, 50 WAKE FOREST L. REV. 761, 768 (2015) ("[S]tatutes should be adopted giving those constituencies enforceable rights that they can wield. The benefit corporation is a modest, but genuine, example of that kind of step forward.").

182. Gilbert, supra note 170.

183. Jack Markell, $A$ New Kind of Corporation to Harness the Power of Private Enterprise for Public Benefit, HUFFPOST (July 22, 2013), http://www.huffingtonpost.com/gov-jackmarkell/public-benefitcorporation_b_3635752.html ("Because of Delaware's leading role in U.S. corporate law, enactment of benefit corporation legislation in my state is critical for these businesses that seek access to venture capital, private equity, and public capital markets.").

184. Plerhoples, supra note 139, at 253. 


\section{Local Impact of Benefit Corporation Legislation}

As of December 31, 2015, 460 public benefit corporations were formed in Delaware, of which 404 were newly formed entities. ${ }^{185}$ Among the 460 benefit corporations, thirty-four have since merged, been dissolved, or otherwise terminated, leaving a net of 426 benefit corporations as of August 2016. ${ }^{186}$ Seven companies submitted the necessary paperwork and converted to this corporate form on the first day of the law's coming into force. ${ }^{187}$ There were, in total, seventy-six benefit corporations incorporating in Delaware in 2013, 159 in 2014, and a record of 225 forming in 2015,188 indicating a growing governance trend toward this corporate form in the state.

An industry analysis of public benefit corporations that incorporated in Delaware within the first three months of the bill's passage showed that the statute contributed to the state's economic growth, though not by attracting investment or creating jobs to the most recessive sectors as its proponents had hoped. Among all companies that converted to benefit corporations in Delaware within the first three months of the bill's enactment, thirty-one percent of them fell within the professional and technical services sector and the financial and insurance sector, ${ }^{189}$ which were the fastest-growing sectors in Delaware from 2013 to 2014. ${ }^{190}$ Consumer retail products, technology, and education each constituted eleven percent of the cohort of the first fiftyfive benefit corporations, which were also the fastest growing industries from 2013 to $2014 .{ }^{191}$ On the other hand, none of those fifty-five benefit corporations were within the real estate, rental, and leasing sector, or the government sector, which were most recessive sectors from 2013 to 2014 in Delaware. ${ }^{192}$ Even though the economic impact from the Delaware benefit corporation statute was not as strong as legislators perhaps anticipated, the legislation had a positive impact on Delaware's economy. Since its introduction, public benefit corporations have contributed several hundred-thousand dollars to Delaware's General Fund in the form of fees and franchise taxes. ${ }^{193}$

185. Geisenberger, supra note 24. A spreadsheet attached to the E-mail regarding all public benefit corporations that has been formed in Delaware that includes their "statement of specific public benefits" (on file with author).

186. Id.

187. B Corporations See Growth During First Year in Del., NEWs J. (Wilmington, Del.), Nov. 24, 2013, 2013 WLNR 29611478.

188. See Geisenberger, supra note 24.

189. Plerhoples, supra note 139, at 262-64 (tracking PBCs incorporated within the first three months by industry and finding that seventeen of fifty-five provided professional services).

190. Table 2, Contribution to Percent Change in Real GDP by State, 2013-2014, supra note 32.

191. See id.

192. See id.

193. Geisenberger, supra note 24. 
Like Connecticut, Delaware media's interest in its public benefit corporation legislation mimicked state legislative actions. From April 2013 to November 2013, there were a total of forty-eight news articles about "public benefit corporation" published in both local media sources like Wilmington News Journal, Delaware Business Blog, and News.Delaware.Gov., and national news sources like National Law Review, JD Supra, and The New York Times. However, there were only seven articles published in 2014. The number of media reports about public benefit corporations increased to thirteen in 2015, as the 2015 Amendments to benefit corporation statute was signed into law. From April 2013 to April 10, 2016, there were seventyone media reports about benefit corporation legislation in Delaware, ${ }^{194}$ as shown in Figure 3.

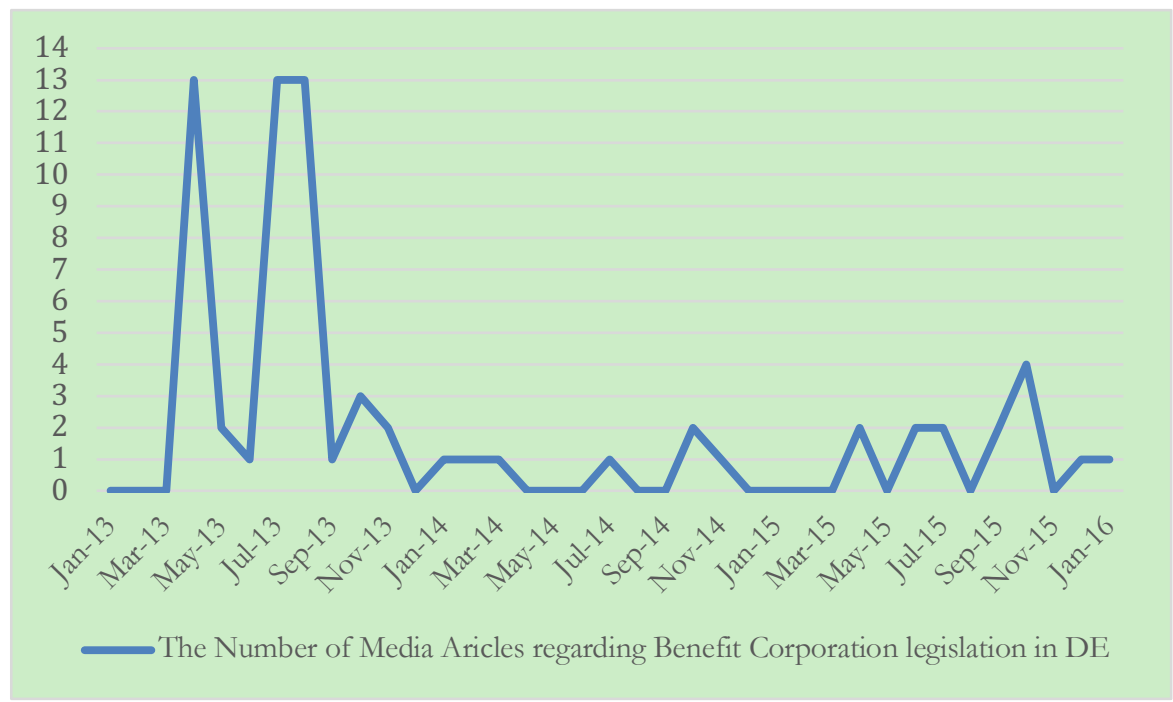

Figure 3: Number of Media Articles Referencing Benefit Corporation in Delaware, January 2013-January 2016195

\section{E. Summary}

The final Section of Part III summarizes the findings from the Virginia, Connecticut, and Delaware case studies in two tables. Table 1 compares the process by which the benefit corporation statutes were passed in the two states, including the number of attempts, amount of time required to pass the legislation, and the number of benefit corporations registered to date.

194. Westlaw "Delaware news" database, search term "public benefit corporation." The results of research is on file with the authors.

195. This chart is based on Westlaw "Delaware News" database. The research covered media articles containing the phrase "benefit corporation" from January 2013 to January 2016. 


\begin{tabular}{|c|c|c|c|c|c|}
\hline State & Title of Legislation & Stakeholders (for/against) & $\begin{array}{c}\text { \# of Attempts } \\
\text { to Pass } \\
\text { Legislation }\end{array}$ & $\begin{array}{l}\text { \# of Months } \\
\text { to Pass } \\
\text { Legislation }\end{array}$ & $\begin{array}{c}\text { \# of Benefit } \\
\text { Corporations } \\
\text { Registered }\end{array}$ \\
\hline Virginia & $\begin{array}{l}\text { An Act to amend the } \\
\text { Code of Virginia by } \\
\text { adding in Chapter } 9 \text { of } \\
\text { Title } 13.1 \text { an article } \\
\text { numbered } 22 \text {, consisting of } \\
\text { sections numbered } 13.1 \text {. } \\
782 \text { throung } 13.1-791 \text {, } \\
\text { relating to benefit } \\
\text { corporations, }\end{array}$ & $\begin{array}{l}\text { Supporters: } \\
\text { Virginia Bar Association; B Lab; } \\
\text { Impact Makers } \\
\text { Opponents-after passage: } \\
\text { Daniel S. Kleinberger; Victoria } \\
\text { Bjorklund }\end{array}$ & 1 & $\begin{array}{c}1.5 \\
\text { (Jan. 12- Feb. } \\
\text { 23) }\end{array}$ & $\begin{array}{c}46 \\
\text { (Mar. 17, } \\
\text { 2016) }\end{array}$ \\
\hline Connecticut & $\begin{array}{l}\text { An Act Concerming } \\
\text { Benefit Corporations and } \\
\text { Encouraging Social } \\
\text { Enterprise; }\end{array}$ & $\begin{array}{l}\text { Supporters: } \\
\text { Gov. Dannel P. Malloy; American } \\
\text { Association of Retired Persons } \\
\text { (AARP); The Tan200 International } \\
\text { Holdings Corporation; BI Cares; } \\
\text { Connecticut Technology Council } \\
\text { (CTC); Simply Smiles; Department } \\
\text { of Economic and Community } \\
\text { Development } \quad \text { (DECD); } \\
\text { Connecticut Innovations (CI); CT } \\
\text { Veterans Chamber of Commerce; } \\
\text { Secretary of the State; CT News } \\
\text { Junkie and the Independent Media } \\
\text { Network; } \\
\text { Connecticut Business \& Industry } \\
\text { Association; B Lab; Connecticut } \\
\text { Bar Association; iMission Partners } \\
\text { LLC; } \\
\text { Choice Business \& Personal } \\
\text { Coaching LLC; reSET; CT } \\
\text { Nonprofits; of Connecticut } \\
\text { Conference of Independent } \\
\text { Colleges (CCIC); } \\
\text { The Walker Group; } \\
\text { GoodStreets; MHW LLC; A Happy } \\
\text { Life; Supriyo B. Chatterjee } \\
\text { Opponents: } \\
\text { CT Bar Association, attorneys }\end{array}$ & 3 & $\begin{array}{c}\text { March, 8, } \\
2012(2 \text { yrs. } \\
\text { from start) } \\
2.5 \text { (Feb. } 7 \text { - } \\
\text { Apr. 24, 2014) }\end{array}$ & $\begin{array}{c}39 \text { (Jan. 24, } \\
\text { 2016) }\end{array}$ \\
\hline Delaware & $\begin{array}{l}\text { An Actto Amend Tittle } 8 \\
\text { of the Delaware Code } \\
\text { Relating to the General } \\
\text { Corporation Lam, }\end{array}$ & $\begin{array}{l}\text { Supporters: } \\
\text { Governor Jack Markell; } \\
\text { Delaware State Bar Association; } \\
\text { Delaware Court of Chancery; } \\
\text { Secretary of State; B-Lab; } \\
\text { Original Opponents: } \\
\text { Corporations Law Council }\end{array}$ & $\begin{array}{c}1 \\
\text { And } \\
\text { Amendments }\end{array}$ & $\begin{array}{c}\begin{array}{l}4 \text { years from } \\
\text { start }\end{array} \\
2.0(\text { Apr. } 18 \text { - } \\
\text { June 13, 2013) }\end{array}$ & $\begin{array}{c}460 \text { (Feb. } 1, \\
2016)\end{array}$ \\
\hline
\end{tabular}

Table 1: Procedural Benefit Corporation Statute Summary Matrix

As is apparent from Table 1, there were many more active stakeholders supporting the benefit corporation statute in Connecticut than Delaware, though the Delaware experience required only a single attempt to pass and was influenced by debate outside of the legislative process. In addition, far more benefit corporations were registered over similar time periods in Delaware than in Connecticut, which has a comparable number as Virginia (even though the latter's economy is roughly twice the size). However, this 
may be largely explained by the special status of Delaware as a seat of U.S. corporate law governance as was discussed above.

The substance of all three benefit corporation statutes is also similar with the important addendum that Delaware departs more significantly from the Model Benefit Corporation Legislation. This may be seen in the differing provisions regarding the legal preservation provision, naming requirement, and appraisal rights shown in Table 2.

\begin{tabular}{|c|c|c|c|c|c|}
\hline State & $\begin{array}{l}\text { Title of } \\
\text { Legislation }\end{array}$ & $\begin{array}{l}\text { Voting requirement for } \\
\text { Conversion }\end{array}$ & $\begin{array}{c}\text { Legacy } \\
\text { preservation } \\
\text { provision }\end{array}$ & $\begin{array}{l}\text { Naming } \\
\text { requirement }\end{array}$ & $\begin{array}{l}\text { Appraisal } \\
\text { Rights }\end{array}$ \\
\hline Virginia & $\begin{array}{l}\text { An Act to amend } \\
\text { the Code of Virginia } \\
\text { by adding in } \\
\text { Chapter } 9 \text { of Title } \\
13.1 \text { an article } \\
\text { numbered } 22, \\
\text { consisting of sections } \\
\text { numbered 13.1-782 } \\
\text { through 13.1-791, } \\
\text { relating to benefit } \\
\text { corporations, }\end{array}$ & $\begin{array}{l}\text { "Any such amendment... } \\
\text { shall be approved by all } \\
\text { shareholders entitled to vote } \\
\text { on the amendment, or if no } \\
\text { shares have yet been issued, } \\
\text { in accordance with } \ 13.1 \text { - } \\
709 . " 196\end{array}$ & $\mathrm{~N} / \mathrm{A}$ & $\begin{array}{l}\text { N/A (but see "A } \\
\text { benefit } \\
\text { corporation.... } \\
\text { its articles, as } \\
\text { initially filed } \\
\text { with the } \\
\text { Commission or } \\
\text { as amended, } \\
\text { shall state that it } \\
\text { is a benefit } \\
\text { corporation." } 197 \text { ) }\end{array}$ & $\mathrm{N} / \mathrm{A}$ \\
\hline Connecticut & $\begin{array}{l}\text { An Act Concerning } \\
\text { Benefit Corporations } \\
\text { and Encouraging } \\
\text { Social Enterprise }\end{array}$ & $\begin{array}{l}\text { "Any such amendment ... } \\
\text { shall be approved by a } \\
\text { minimum status vote (the } \\
\text { vote of shareholders of each } \\
\text { class or series entitled to cast } \\
\text { at least two-thirds of the } \\
\text { votes that shareholders of the } \\
\text { class or series are entitled to } \\
\text { cast on the action)"198 }\end{array}$ & $\begin{array}{l}\text { Allowing the } \\
\text { owners of a } \\
\text { benefit } \\
\text { corporation to } \\
\text { enact an } \\
\text { optional clause } \\
\text { in their articles } \\
\text { of incorporation } \\
\text { that will ensure } \\
\text { that their benefit } \\
\text { corporation } \\
\text { remains a social } \\
\text { enterprise in } \\
\text { perpetuity. }\end{array}$ & $\mathrm{N} / \mathrm{A}$ & Yes. ${ }^{200}$ \\
\hline Delaware & $\begin{array}{l}\text { An Act to Amend } \\
\text { Title } 8 \text { of the } \\
\text { Delaware Code } \\
\text { Relating to the } \\
\text { General Corporation } \\
\text { Law; }\end{array}$ & $\begin{array}{l}\text { " } \ldots \text { the approval of } 2 / 3 \text { of } \\
\text { the outstanding stock of the } \\
\text { corporation entitled to vote } \\
\text { thereon." } \\
\text { (It was Ninety percent in S.B. } \\
47,147 \text { th Gen. Assemb. } \\
\text { (Del. 2013)) }\end{array}$ & $\mathrm{N} / \mathrm{A}$ & $\begin{array}{l}\text { "[M]ay contain } \\
\text { the words } \\
\text { "public benefit } \\
\text { corporation," or } \\
\text { the abbreviation } \\
\text { "P.B.C.," or the } \\
\text { designation } \\
\text { "PBC,"202 (It } \\
\text { was mandatory } \\
\text { in S.B. 47, 147th } \\
\text { Gen. Assemb. } \\
\text { (Del. 2013)) }\end{array}$ & $\begin{array}{l}\text { Yes. }{ }^{203} \text { (There } \\
\text { was no such } \\
\text { provision in } \\
\text { S.B. 47, 147th } \\
\text { Gen. Assemb. } \\
\text { (Del. 2013)) }\end{array}$ \\
\hline
\end{tabular}

Table 2: Substantive Benefit Corporation Statute Summary Matrix

196. See H.B. 2358, Gen. Assemb., 2011 Sess. $\$ 13.1-785$ (Va. 2011).

197. Id. $\int 13.1-784$.

198. S.B. 23, 2014 Gen. Assemb., Feb. Sess. \$S 2, 5 (Conn. 2014).

199. Id. $\iint 6_{6-7 .}$

200. Id. $\$ 16$.

201. S.B. 75, 148th Gen. Assemb., 1st Reg. Sess. @ 363(c) (Del. 2015).

202. Id. \$362(c).

203. Id. $\$ 363(\mathrm{~b})$. 
Thus, as the case studies in Part III demonstrate, it seems that wide stakeholder engagement in the adoption process is critical for enhancing legitimacy and, ultimately, is important for the success of benefit corporations. The high degree of both grass roots support and debate between stakeholders (and media attention) for benefit corporation legislation in Delaware, for example, correlates with the relative success of that state's benefit corporation registration efforts, as shown in Table 1. Similarly, the relatively more contentious approval process and discussions among differing stakeholders in Connecticut correlates with a higher number of benefit corporations registered relative to Virginia when controlling for the overall size of the economy in question. This link is discussed further in Part III, and might be related to the corresponding media coverage rates. The shared factor in all three cases was opposition by attorneys, whether institutionally through bar associations or individually by corporate lawyers. It seems that the corporate law profession is not inherently attracted to innovation for socially responsible enterprises. However, when entrepreneurs, businesses and non-profits made the case for a new vision of the relationship between business and society, then buyin from the legal profession ${ }^{204}$ correlated to a higher degree of uptake, reflected by the number of entities adopting the benefit corporation form.

\section{TRANSATLANTIC APPROACHES TO DEFINING "SOCIAL ENTERPRISE"}

Concerns regarding short-term shareholder wealth maximization discussed in Part II are not confined to the United States; indeed, entrepreneurs ranging from Richard Branson to Muhammad Yunus have voiced their frustration in this vein. ${ }^{205}$ The private sector is responding with more than $\$ 3$ trillion invested in socially responsible firms globally. 206 Yet, despite this widespread interest, general agreement as to the definition of key terms, including "social entrepreneurship," is lacking in the relevant international academic literature, but generally combines some "elements of the social purpose, the market orientation, and financial-performance

204. See Dorff, supra note 171, at 88 (In Delaware, “ $[\mathrm{t}]$ he Council's initial view was that corporate law already functioned quite well, and that the best way to restrain corporate conduct that had a negative impact on society or the environment was through direct regulation, not by tinkering with corporate governance law. The Council was eventually persuaded, however, after B Lab introduced the members to entrepreneurs, businesses, and investors who desired to organize their companies as benefit corporations. The Council concluded that Delaware ought to offer businesses the flexibility to adopt social goals.”) (internal footnotes omitted).

205. See Robert T. Esposito, The Social Enterprise Revolution in Corporate Law: A Primer on Emerging Corporate Entities in Europe and the United States and the Case for the Benefit Corporation, 4 WM. \& MARY BUS. L. REV. 639, 642 (2013).

206. See, e.g., Alina Tugend, Picking Stocks That Don't Sin, N.Y. TIMES (Mar. 17, 2007), https://www.nytimes.com/2007/03/17/business/17shortcuts.html?pagewanted=print. 
standards of business." 207 For example, the Canadian Centre for Social Entrepreneurship defines "social entrepreneurs" as "leaders in the field of social change ... [that] can be found in the private, public, and non-profit sectors," 208 whereas other authors have defined "social entrepreneurs" merely "as non-profit executives, who pay increasing attention to market forces." 209 As such, there is a lack of consensus on first principles, which in turn is mirrored in the array of socially responsible corporate forms emerging across Europe.

\section{A. Unpacking European Socially Responsible Corporate Law}

Europe in many ways is considered to be "the birthplace of modern social enterprise." 210 Yet European corporate law is distinct from its U.S. cousin along a number of dimensions, including the former's emphasis on establishing institutional structures that are designed "to pursue a social good in a stable and continuous way through the production of goods or services of general-interest." 211 In other words, there is a strong collectivist undercurrent in European corporate law that is largely absent in U.S. law, enabling groups to come together to create organizations with "specific and well defined social" goals in mind that in turn boasts complementary institutional characteristics. ${ }^{212}$ However, despite the collectivist European mindset in corporate law, the way that many European nations-and the European Union itself, with the notable exception of the United Kingdom-have approached the topic is narrower than in the United States, which has artificially limited the number and type of such firms. Given this narrower definition that preferences social goods, environmental causes are often sidestepped relative to the United States. ${ }^{213}$

As within the U.S. context, in which social enterprises can take an array of forms including benefit corporations, European organizations boast a range of fluid choices when it comes to picking socially optimal corporate forms. 214 Traditionally, most socially responsible organizations within Europe opted for either the cooperative or association models as most advantageous - both of which are inward-facing models designed more to benefit members than are benefit corporations - with France and Belgium pioneering social enterprises that provide greater flexibility to compete in

207. See Giulia Galera \& Carlo Borzaga, Social Enterprise: An International Overview of its Conceptual Evolution and Legal Implementation, 5 SOC. ENTERPRISE J. 210, 212 (2009).

208. Id. at 215.

209. Id.

210. Esposito, supra note 205, at 671.

211. Galera \& Borzaga, supra note 207 , at 213

212. See id.

213. Esposito, supra note 205, at 672.

214. See Galera \& Borzaga, supra note 207 , at 220 
the open marketplace. ${ }^{215}$ France began experimenting with a new corporate form-the Co-operative Society of the Common Interest (Société Coopérative d'Interet Collectif or SCIC) — in 2001, which empowered local communities to establish cooperatives and gain access to public funds, while still pursuing traditional business functions. ${ }^{216}$ The law also diversified the stakeholders within such organizations, which may have also slowed down the growth of SCICs. ${ }^{217}$ Belgium has been a pioneer in European socially responsible corporate law, ${ }^{218}$ such as may be seen by the rise of the "social purpose company" (Société à Finalité Sociale) in 1995.219 Unlike in other European nations, in Belgium these firms can be used by any private firm with no reservations on the type of public purpose involved.220 However, these firms are only allowed to seek a "limited profit" and must "define the social good" that they are targeting. Italy allowed for the formation of social enterprises beginning in 1991,221 which has since led to the formation of more than 7,000 Italian social enterprises employing some 250,000 workers, and eventually to its 2015 benefit corporation statute. ${ }^{222}$ Other nations followed Italy's success in this space, including Portugal, Spain, and Poland; however, many continue to limit the activities of social enterprises. ${ }^{223}$

Today in modern Europe, socially responsible corporate law may be "defined by different types of social cooperatives aimed at providing work integration services and personal services for the disadvantaged." 224 The most popular type of socially responsible business form remains social cooperatives, which are considered to be "the most widespread social enterprise entities in Europe" with nearly all the European nations having authored their own version of social cooperative entity legislation. 225 The most popular version of these cooperatives is a Work Integration Social Enterprise (WISE) business form, whose goal it is "to help low-qualified

215. See id.

216. Id. at 220

217. Id.

218. Id.

219. Id. at 221; Esposito, supra note 205, at 673 ("Belgium's legislation did not create a new corporate entity, but rather created a certification available to all types of business organizations. In order to obtain this certification, the organization must define a profit allocation policy and permit employee participation in the organization's governance structure through ownership of capital shares."). As Matthew Doeringer notes, in the eight years following the creation of Belgium's scheme, "only 400 SFSs registered with the Belgian government." Id. at 674.

220. Galera \& Borzaga, supra note 207 , at 222.

221. Id.

222. Id.

223. For example, Portugal's 1998 social enterprise law was focused on the cause of giving "support to vulnerable groups (children, youth, disadvantaged persons, old persons), families and socially disadvantaged communities in view of their economic integration, as well as to Portuguese emigrants in difficulties; to establish support programs; and to promote both education and work integration of socially disadvantaged groups." Id. at 220.

224. Esposito, supra note 205, at 671.

225. Id. at 672 . 
unemployed people, who are at risk of permanent exclusion from the labour market." 226 Table 3 summarizes some of the predominant socially responsible corporate forms in Europe.

\begin{tabular}{|l|l|l|l|}
\hline Country & Legal forms used & \multicolumn{1}{c|}{ Law/Year } & \multicolumn{1}{c|}{ Activities } \\
\hline Italy & Social cooperative & $381 / 1991$ & $\begin{array}{l}\text { Social services (a-type) } \\
\text { Work integration (b- } \\
\text { type) }\end{array}$ \\
\hline Spain & Social cooperative societies & $\begin{array}{l}\text { National law 27/1999 } \\
\text { and regional laws in 12 } \\
\text { autonomous regions } \\
(1993-2003)\end{array}$ & $\begin{array}{l}\text { Assistance services in } \\
\text { the fields of health, } \\
\text { education, culture or any } \\
\text { activity of a social nature } \\
\text { Work-integration }\end{array}$ \\
\hline Portugal & Social Solidarity cooperatives & $\begin{array}{l}\text { Co-operative code (Law } \\
n^{\circ} \text { 51/96 of 7 September } \\
1996) \text { and Legislative } \\
\text { decree no } 7 / 98 \text { of 15 } \\
\text { January 1998. }\end{array}$ & $\begin{array}{l}\text { Work-integration of } \\
\text { vulnerable groups }\end{array}$ \\
\hline France & $\begin{array}{l}\text { General-interest cooperative } \\
\text { societies }\end{array}$ & $\begin{array}{l}\text { Law of 17 July 2001 } \\
\text { Tabien }\end{array}$ & $\begin{array}{l}\text { Production or provisions } \\
\text { of goods and services of } \\
\text { collective interest }\end{array}$ \\
\hline
\end{tabular}

Table 3: European Social Enterprises Designations ${ }^{227}$

Eventually, the benefit corporation form made its way to the EU in 2016 when Italy passed a law allowing for the creation of a form, Società Benefit, based primarily, but not completely, on the US benefit corporation form. ${ }^{228}$ The primary distinctions of the Italian form are:

1) the "Società Benefit" must list in the bylaws the specific benefit activities, 2) the annual report must be more detailed than the U.S. Benefit Corporation, 3) no limitation of liability clause exists for Benefit Corporation directors with respect to third party lawsuits and 4) the scope of the law applies not only to for-profit companies, but also to limited-profit companies. 229

An outlier in the European experience with developing socially responsible corporate law is the United Kingdom, which has taken a broader view of "for-profit, mission-driven social enterprise" and "now enjoys the most robust social enterprise sector in Europe." 230 As such, the United Kingdom's experience in this sector is especially relevant given Brexit before delving into the road ahead and applying lessons learned from the case

226. Id. (quoting Jacques Defourny \& Marthe Nyssens, Social Enterprise in Europe: Recent Trends and Developments, 4 SOC. ENTERPRISE J. 202, 207 (2008)).

227. Galera \& Borzaga, supra note 207, at 221.

228. See Alissa Pelatan \& Roberto Randazzo, The First European Benefit Corporation: Blurring the Lines Between 'Social' and 'Business,' ESELA 1 (June 2016), https://www.bwbllp.com/file/benefit-corporationarticle-june-16-pdf.

229. Id. at 4.

230. Esposito, supra note 205, at 674. 
studies in Part III toward advancing international socially responsible corporate law.

\section{B. Case Study: The UK's Community Interest Company Approach}

The United Kingdom is experimenting with an array of legislative approaches to furthering the cause of socially responsible corporate law, including the Community Interest Company (CIC) approach, ${ }^{231}$ which is "designed for enterprises that want to use their profits and assets for the public good[, particularly] to complement government services at the community level in areas such as childcare provision, social housing, community transport or leisure."232 Prior to the rise of CICs in the United Kingdom there was a frustration, according to Stephen Lloyd ${ }^{233}$ - one of the CICs' chief architects-with English corporate law, particularly that it made it "quite complicated to embed social purposes in a legal form because there was not an off-the-shelf, simple-to-use legal entity ready for social enterprise unless you used the old-fashioned industrial and provident societies - the law for which has not been updated since 1965.”234

The result was the CIC, recognized as part of the 2004 Companies Act. ${ }^{235}$ These organizations are typically limited liability firms overseen by boards of directors and subject to checks and balances to ensure that they promote community interests. ${ }^{236} \mathrm{CICs}$ in the United Kingdom are overseen by the CIC Regulator, and must register with the Companies House, a body similar in function to the Secretaries of State in the United States, to ensure that the activity in question is "for the benefit of the community." 237 Assets are also "locked" in CICs so as to further ensure their community benefit. 238 Despite these strictures, CICs have proven to be incredibly popular within Britain; more than 6,400 had been registered as of 2012, making them the most successful socially responsible corporate form in Europe. 239

Part of the reason for the success of the United Kingdom's socially responsible investment culture are the incentives that the British government put into place to spur the uptake of new corporate forms. These include: (1) the creation of an informative website, (2) the opening of

231. See Galera \& Borzaga, supra note 207, at 224.

232. Id.

233. Id.

234. Stephen Lloyd, Transcript: Creating the CIC, 35 VT. L. REV. 31, 33 (2010).

235. Companies (Audit, Investigations and Community Enterprise) Act 2004, c. 27, \ 26 (UK).

236. Esposito, supra note 205, at 675.

237. Id. at 676; The Community Interest Company Regulations 2005, SI 2005/1788, art. 2, q 8 (UK).

238. For more on "asset locks" in CICs, see Esposito, supra note 205, at 676.

239. Id. at 676-77; Community Interest Company Register, DEP'T FOR BUS. INNOVATION \& SKILLS, http://webarchive.nationalarchives.gov.uk/+/http://www.bis.gov.uk/cicregulator/cic-register (last updated Apr. 4, 2012). 
"regional social enterprise development centers," (3) the selection of "thirtyfive social enterprise ambassadors tasked with spreading information in local communities," (4) the "establishment of a $£ 10$ million fund for investment in social enterprise," (5) and the "creation of programs to develop better metrics for valuing the social benefits produced by social enterprise." 240 However, CICs are not without their critics, including those that focus on the restrictive dividend policies in this regime, and the lack of any tax breaks or benefits for these corporate forms. ${ }^{241}$ Table 4 highlights the CIC along with new socially responsible legal forms being tried across the EU.

More recently in the United Kingdom, the Office for Civil Society undertook a study of mission-led businesses, and an Advisory Panel led discussions across a wide variety of stakeholders. ${ }^{242}$ One of the ten recommendations was to potentially offer a benefit corporation option in the United Kingdom. ${ }^{243}$ Whether or not the United Kingdom ultimately adopts something akin to the benefit corporation, it opened the door to wider discussions about what it means to benefit wider society and how that might be achieved by traditionally profit-seeking corporations.

240. Esposito, supra note 205, at 675.

241. Id. at 678 .

242. See David Ainsworth, Bring B Corp Model to UK, Government-Backed Review Recommends, CIVILSOCIETY (Dec. 6, 2016), https://www.civilsociety.co.uk/news/bring-b-corp-model-to-ukgovernment-backed-review-recommends.html.

243. Id. 


\begin{tabular}{|c|c|c|c|c|c|}
\hline Country & $\begin{array}{c}\text { Legal forms } \\
\text { used }\end{array}$ & $\begin{array}{c}\text { Profit } \\
\text { distribution } \\
\end{array}$ & Governance & $\begin{array}{c}\text { Entrepreneurial } \\
\text { model }\end{array}$ & $\begin{array}{c}\text { Definition of } \\
\text { social aim }\end{array}$ \\
\hline $\begin{array}{l}\text { Belgium } \\
\text { Law of } 13 \\
\text { April } 1995\end{array}$ & $\begin{array}{l}\text { Limited } \\
\text { company; } \\
\text { Limited } \\
\text { liability } \\
\text { cooperative } \\
\text { society; } \\
\text { Private } \\
\text { limited } \\
\text { liability } \\
\text { society }\end{array}$ & $\begin{array}{l}\text { Redistribution } \\
\text { of profits is } \\
\text { possible, but } \\
\text { limited }\end{array}$ & $\begin{array}{l}\text { Participatory } \\
\text { nature }\end{array}$ & & $\begin{array}{l}\text { Activities that } \\
\text { are aimed at } \\
\text { pursuing a } \\
\text { social goal. } \\
\text { What } \\
\text { constitutes a } \\
\text { social goal } \\
\text { results from } \\
\text { constitutive } \\
\text { elements } \\
\text { foreseen by the } \\
\text { legislation. }\end{array}$ \\
\hline $\begin{array}{l}\text { Italy } \\
\text { Law n. } 118 \\
\text { of } 13 \text { June } \\
2005\end{array}$ & $\begin{array}{l}\text { Associations; } \\
\text { Foundations; } \\
\text { Co- } \\
\text { operatives; } \\
\text { For-profit } \\
\text { enterprises }\end{array}$ & $\begin{array}{l}\text { Direct and } \\
\text { indirect } \\
\text { distribution } \\
\text { of profits } \\
\text { prohibited }\end{array}$ & $\begin{array}{l}\text { Participatory } \\
\text { nature }\end{array}$ & Collective & $\begin{array}{l}\text { Production or } \\
\text { exchanges of } \\
\text { services in the } \\
\text { sectors of } \\
\text { social and } \\
\text { health } \\
\text { assistance, } \\
\text { education and } \\
\text { training, } \\
\text { environmental } \\
\text { protection, } \\
\text { social tourism, } \\
\text { cultural } \\
\text { services or } \\
\text { work } \\
\text { integration of } \\
\text { disadvantaged } \\
\text { persons } \\
\text { independently } \\
\text { from the field } \\
\text { of activity of } \\
\text { the enterprise }\end{array}$ \\
\hline $\begin{array}{l}\text { Finland } \\
\text { Law n. } \\
1351 / 2003\end{array}$ & $\begin{array}{l}\text { All } \\
\text { enterprises } \\
\text { regardless of } \\
\text { their legal } \\
\text { form and } \\
\text { ownership } \\
\text { structure }\end{array}$ & $\begin{array}{l}\text { Distribution } \\
\text { of profits } \\
\text { allowed with } \\
\text { no constraints }\end{array}$ & $\begin{array}{l}\text { Participatory } \\
\text { governance } \\
\text { not } \\
\text { envisaged }\end{array}$ & Not relevant & $\begin{array}{l}\text { Social } \\
\text { enterprises } \\
\text { have to employ } \\
\text { at least } 30 \% \text { of } \\
\text { people with } \\
\text { disability and } \\
\text { long-term } \\
\text { unemployed }\end{array}$ \\
\hline $\begin{array}{l}\text { United } \\
\text { Kingdom } \\
\text { Community } \\
\text { Interest } \\
\text { Company } \\
\text { regulations } \\
2005\end{array}$ & $\begin{array}{l}\text { Enterprises } \\
\text { regulated by } \\
\text { Companies } \\
\text { Act of } 1985\end{array}$ & $\begin{array}{l}\text { Partial } \\
\text { distribution } \\
\text { of profits } \\
\text { allowed }\end{array}$ & $\begin{array}{l}\text { Participatory } \\
\text { nature }\end{array}$ & $\begin{array}{l}\text { Collective and } \\
\text { individual }\end{array}$ & $\begin{array}{l}\text { Wide range of } \\
\text { activities that } \\
\text { correspond to } \\
\text { the needs of } \\
\text { communities. } \\
\text { Social } \\
\text { definition } \\
\text { assessed by the } \\
\text { Regulator }\end{array}$ \\
\hline $\begin{array}{l}\text { EMES } \\
\text { Definition }\end{array}$ & $\begin{array}{l}\text { All legal } \\
\text { forms } \\
\text { admitted }\end{array}$ & $\begin{array}{l}\text { Partial } \\
\text { distribution } \\
\text { of profits } \\
\text { allowed }\end{array}$ & $\begin{array}{l}\text { Participatory } \\
\text { nature }\end{array}$ & Collective & $\begin{array}{l}\text { Wide range of } \\
\text { activities aimed } \\
\text { at pursuing an } \\
\text { explicit social } \\
\text { goal }\end{array}$ \\
\hline
\end{tabular}

Table 4: Recent European Social Enterprise Legal Frameworks ${ }^{245}$ 


\section{Looking Ahead and Applying Lessons Learned}

In the wake of the 2008-2009 global financial crisis, there was a new wave of social enterprise legislation across Europe, as seen in the U.K. case study. 246 Moving forward, the EU adopted a "Europe 2020" strategy to help foster "smart, sustainable and inclusive growth" across the continent. ${ }^{247}$ One of the initiatives within the Europe 2020 Strategy is the need to boost social entrepreneurship, ${ }^{248}$ particularly social investment funds to help expand the nearly five million European jobs now supported by social cooperatives. ${ }^{249}$ Indeed, according to one 2009 study, nearly twenty-five percent of all European businesses fell under the heading of "social enterprise." ${ }^{250}$ Beyond scaling up social investment funds across the EU, other proposals for expanding the sector have included mechanisms to enhance the visibility of socially responsible best practices such as a "public database of labels and certifications" that socially responsible firms could contribute to and share. ${ }^{251}$

Yet "[d]espite this conclusion, the suggestions of the European Commission continue to reflect a narrow view of social enterprises as strictly charitable organizations." 252 Myriad areas for improvement remain, including geographically. Eastern Europe, for example, has lagged behind Western Europe due in part to "cultural opposition and skepticism to cooperative forms" and "the absence of legal frameworks to regulate cooperatives." 253

In comparison, the Italian adoption of a benefit corporation framework in the Società Benefit-different from social enterprise law in large part because the enterprise can also be profit seeking-is "seen as a new revolutionary step forward, within a context traditionally static and sometimes obsolete."254 Similarly, other European nations could learn from the comparative case studies detailed in Part III, including the impact of grassroots support and media attention to help drive interest in new corporate forms like benefit corporations.

In particular, grass roots support is vital, especially efforts aimed at influencing influential jurists and policymakers. This was true in the case of

246. Esposito, supra note 205, at 671.

247. Eur. COMM'N, Europe 2020: A European STRATEgy For SMART, Sustainable AND INCLUSIVE GROWTH 3 (Mar. 3, 2010).

248. Id. at 19; Esposito, supra note 205, at 679.

249. Id.

250. Siri TerJeSEN ET AL., GLOBAL ENTREPRENEURSHIP MONITOR: 2009 REPORT ON SOCIAL ENTREPRENEURSHIP 20 (2011), https://www.gemconsortium.org/report/gem-2009-report-onsocial-entrepreneurship.

251. Esposito, supra note 205, at 680.

252. Id. at 681.

253. Id. at 673.

254. Pelatan \& Randazzo, supra note 228, at 6. 
Delaware, for example, in that Chief Justice Strine's advocacy was instrumental in the eventual passage (and subsequent amendment) of the Delaware PBC statute. Regarding the substance of these laws, as Delaware - and to a lesser extent Connecticut and Virginia—makes clear, states and other jurisdictions can and should apply their own unique perspective and variations to the Model Law; experimentation and evolution are part and parcel of polycentric governance. Eventually, as more states and nations craft versions of these laws, businesses will vote by seeking out those jurisdictions that are best suited to their corporate visions. This is already happening to an extent in Delaware as more than 450 firms have already sought out registration in that jurisdiction. Such an approach could also aid in norm building, with states and firms acting as norm entrepeneurs that could eventually cause a polycentric "norm cascade" and help usher in a new era in responsible corporate governance. 255

However, learning goes both ways. The United States could absorb lessons from the United Kingdom's incentive structures and the popularity of the United Kingdom's CIC scheme. It could also learn from EU countries' experiments to find the best legal organizational match for social entrepreneurship, and from those countries that are willing to try new ideas from other legal jurisdictions, illustrated by the Italian tailored adoption and the United Kingdom's consideration of the benefit corporation form.

Globally, corporate law may be subject to modification for many years to come. The approach may be described as polycentric, since a choice architecture for socially responsible organizations "encourages experimental efforts by multiple actors," 256 embraces self-regulation, and focuses on multi-stakeholder governance including both the public and private sectors. Just as the states are laboratories for democracy in the U.S. federal system, as Justice Louis D. Brandeis famously observed, ${ }^{257}$ so too are firms and nations laboratories for corporate governance of the different forms of socially responsible business.

\section{CONCLUSiON}

Comparative coverage of corporate law development is regrettably underdeveloped, particularly comparing the experience of U.S. states and foreign nations in the passage of novel corporate laws. This Article has attempted to fill this gap by uncovering some of the processes and stakeholders involved in the rapid uptake of benefit corporation statutes in

255. See Martha Finnemore \& Kathryn Sikkink, International Norm Dynamics and Political Change, 52 INT’L ORG. 887, 895-98 (1998).

256. Elinor Ostrom, A Polycentric Approach for Coping with Climate Change 32 (World Bank, Policy Research Working Paper No. 5095, 2009), https://tinyurl.com/y73z4e4e.

257. See New State Ice Co. v. Liebmann, 285 U.S. 262, 311 (1932) (Brandeis, J., dissenting). 
the United States, zeroing in on the experiences of Virginia, Connecticut, and Delaware. As the remaining sixteen states without such statutes on the books consider their options, it is worth noting the benefits of building grassroots support for such efforts that can, in turn, galvanize media attention. Further, proponents should not fear pushback-in fact, this can be a galvanizing force, as was seen in the Connecticut experience. More work also needs to be done to trace the relative success rates of benefit corporations that are being organized across myriad state laws, and similar foreign laws, so as to better understand which experiments are bearing fruit. But just as Rome was not built in a day, the evolution of corporate law from Ancient Rome to the present has been a long arch; perhaps through such work, we can help ensure that, during this most recent chapter in the evolution of the firm, it bends toward justice. 
Copyright of Virginia Journal of International Law is the property of Virginia Journal of International Law and its content may not be copied or emailed to multiple sites or posted to a listserv without the copyright holder's express written permission. However, users may print, download, or email articles for individual use. 